\title{
Territorial Governments and the Limits of Formalism
}

\author{
Gary Lawson $\dagger$
}

\section{INTRODUCTION}

For much of this nation's history, the governance of American territories, such as the island of Guam, was one of the most significant and oftlitigated problems of American constitutional law. In modern times, however, issues of territorial governance have been reduced to the status of constitutional arcana. Professor Lawson maintains that this frequently neglected problem of territorial governance is an ideal context in which to conduct the resurgent modern debate concerning separation of powers theory. Accordingly, Professor Lawson undertakes a formalist analysis of the principal institutions of American territorial governance, finding all of them incompatible with a formalist understanding of separation of powers. He then critically discusses the constitutional history of these territorial institutions-a history that represents the Supreme Court's most consistent, and perhaps earliest, rejection of formalist methodology. Finally, he argues that the political consequences of applying formalism to territorial administration need not be as profound as a straightforward analysis might suggest.

The 1980s were eventful times for separation of powers enthusiasts. The decade yielded an uncommonly large number of important Supreme Court decisions concerning the Constitution's imternal allocation of federal governmental authority; ${ }^{1}$ all told, the Court decided ten major

$\dagger$ Assistant Professor, Northwestern University School of Law. B.A. 1980, Clarenont Men's College; J.D. 1983, Yale Law School. I have benefited from the questions and comments of many people, nost notably Akhil Amar, John Harrison, Lee Liberman, Mike Rappaport, Marty Redish, and Judith Resnik. Special thanks are due to Herman Marcuse, who has been an institution at the United States Department of Justice during six different decades, and who first brought to nyy attention the peculiar problenis posed by the Guamanian governor. I am grateful to the Civil Liability Program at Yalc Law School and the Julius Rosenthal Fund for support during various stages of this Article's production.

1. "Separation of powers" is a term often used but seldom defined. If the statement in the text is taken as a formal definition, then there were actually far nore "separation of powers" cases decided in the 1980s than I suggest below. For example, judicial deference to administrative decisionmaking is sonetimes thought to raise constitutional as well as statutory questions concerning inter-branch allocations of authority. See Chevron U.S.A., Inc. v. Natural Resources Defense Council, Inc., 467 U.S. 837, 864-66 (1984) (dictum) (suggesting that the Constitution may require judicial deference to reasonable agency interpretations of statutes, at least where such interpretations involve the exercise of policymaking discretion); Farina, Statutory Interpretation and 
cases, ${ }^{2}$ plus a few minor ones, ${ }^{3}$ in which such issues of constitutional structure played a central role. These often sharply divided decisions enployed a bewildering array of inconsistent inethodologies, alternately raising and dashing the hopes both of formalists (such as inyself) who advocate strict adherence to the Constitution's particular tripartite structure and of functionalists who urge flexibility to accommodate the modern administrative state. ${ }^{4}$ The lower federal courts also dealt with a substantial number of separation of powers questions, ranging froin

the Balance of Power in the Administrative State, 89 CoLum. L. Rev. 452 (1989) (critically discussing Chevron's purported constitutional underpinnings). More sweepingly, every statutory or constitutional case invoking an incorrect precedent inplicates "separation of powers" in an inportant sense. See infra note 91. Applying the term "separation of powers" to these usages, lowever, involves too great a departure from the ordinary understanding of the term. Its usual meaning corresponds reasonably well to the range of issues represented by the cases cited at infra notes 2 \& 3 .

2. Mistretta v. United States, 488 U.S. 361 (1989) (uplolding United States Sentencing Commission's authority to pronulgate binding sentencing guidelines); Morrison v. OIson, 487 U.S. 654 (1988) (sustaining prosecutorial autlority of an independent counsel appointed by a special court and removable only for cause); Young v. United States ex rel. Vuitton et Fils S.A., 481 U.S. 787 (1987) (plurality opinion) (endorsing a federal court's power to appoint attorneys to prosecute contenupt actions); Conımodity Futures Trading Comm'n v. Schor, 478 U.S. 833 (1986) (permitting adjudication of state law counterclaims by an administrative agency); Bowsher v. Synar, 478 U.S. 714 (1986) (invalidating conferral of executive budgetary authority on the congressionally removable Comptroller General); Thoinas v. Union Carbide Agric. Prod. Co., 473 U.S. 568 (1985) (approving Inandatory arbitration, with limited court review, of disputes under the Federal Insecticide, Fungicide, and Rodenticide Act concerning the compensation due frone "follow-on" registrants to prior registrants of similar products, for the use of the latter's research data provided to the Environmental Protection Agency); INS v. Chadha, 462 U.S. 919 (1983) (invalidating a one-house legislative veto); Northern Pipeline Constr. Co. v. Marathon Pipe Line Co., 458 U.S. 50 (1982) (invalidating adjudication of state law contract claims by bankruptcy judges); Dames \& Moore v. Regan, 453 U.S. 654 (1981) (giving effect to an executive order nullifying attachunents of Iranian property and halting pending judicial proceedings against Iran); United States v. Raddatz, 447 U.S. 667 (1980) (permitting federal magistrates to preside over suppression hearings, subject to district courts' de novo redetermination of the findings).

3. Skinner v. Mid-America Pipeline Co., 109 S. Ct. 1726 (1989) (upholding congressional delegation of authority to the Secretary of Transportation to inposc fees on regulated gas pipeline conpanies); United States Senate v. FTC, 463 U.S. 1216 (1983), mem. affg Consuners Union of U.S., Inc. v. FTC, 691 F.2d 575 (D.C. Cir. 1982) (invalidating a two-house legislative veto); United States House of Representatives v. FTC, 463 U.S. 1216 (1983) (same case). Compare Public Citizen v. United States Dep't of Justice, 109 S. Ct. 2558, 2572-73 (1989) (avoiding separation of powers problen by construing the Federal Advisory Committee Act (FACA) to be inapplicable to consultations concerning judicial nominees between the Department of Justice and private groups) with id. at 2573-74 (Keunedy, J., concurring) (concluding that the FACA applies to sueh consnltations and is an unconstitutional interference with the President's appointment power); compare also Industrial Union Dep't, AFL-CIO v. American Petroleum Inst., 448 U.S. 607, 646 (1980) (plurality opinion) (avoiding consideration of constitutional problems with delegation of power by narrowly construing the Occupational Safety and Health Act (OSHA) of 1970) with $i d$. at 671 (Relinquist, J., concurring) (construing the statute inore broadly and finding it unconstitutional on delegation grounds).

4. By my reckoning, Synar and Chadha were predoıninantly formalist decisions; Mistretta, Morrison, Vuitton, Schor, Thomas, and Dames \& Moore were functionalist; Raddatz was consistent with either approach; and Marathon was consistent with neither. For discussion of formalism and functionalism, see infra text accompanying notes 15-28. 
whether the President can exercise a pocket veto ${ }^{5}$ when an agent of Congress is available to receive the return of a bill ${ }^{6}$ to whether the appointments clause ${ }^{7}$ applies to officials of an interstate compact agency. ${ }^{8}$ Moreover, many of these cases were instigated or welcomed by important actors in the executive brancl,, whose frequent and forceful pronouncements-both in and out of court-on numerous controversial separation of powers matters helped give the subject an uncommon public visibility. ${ }^{9}$ In all, the decade witnessed the most varied and sustained assault on the institutional structure of the federal government in lialf a century.

There were several near misses as well. ${ }^{10}$ One case in particular stands out as the proverbial big one that got away, and it escaped with virtually no recognition that it was ever on the hook. In 1985, the Nintlı

5. See U.S. CoNST. art. I, § 7, cl. 2 ("If any Bill shall not be returned by the President within ten Days (Sundays excepted) after it shall have been presented to him, the Same shall be a Law, in like Manner as if he had signed it, unless the Congress by their Adjournment prevent its Return, in which Case it shall not be a Law."). "Pocket veto" is the common term applied to the presidential practice of holding a bill without signing it in the last ten days before Congress adjourns. See J. WILSON, AMERICAN GOVERNMENT 343 (1989).

6. See Barnes v. Kline, 759 F.2d 21 (D.C. Cir. 1984), vacated as moot, 479 U.S. 361 (1987).

7. U.S. CoNST. art. II, § 2, cl. 2, quoted at infra text accoinpanying note 59.

8. See Seattle Master Builders Ass'n v. Pacific N.W. Elec. Power \& Conservation Planning Council, 786 F.2d 1359 (9th Cir. 1986), cert denied, 479 U.S. 1059 (1987). For a sampling of cases in which a decision on the nerits was reached at sone stage, see Ameron, Inc. v. United States Army Corps of Eng'rs, 809 F.2d 979 (3d Cir. 1986) (upholding a provision of the Competition in Contracting Act automatically staying execution on challenged government contracts until the congressionally removable Conuptroller General issues recommendations on the challenge), cert. dismissed, 488 U.S. 918 (1988); Melcher v. Federal Opeu Mkt. Comm., 644 F. Supp. 510 (D.D.C. 1986) (holding that members of the Federal Reserve Board's Federal Open Market Committee are not federal officers subject to the appointments clause), affd on other grounds, 836 F.2d 561 (D.C. Cir. 1987), cert. denied, 486 U.S. 1042 (1988); Borders v. Reagan, 518 F. Supp. 250 (D.D.C. 1981) (holding that the President cannot reniove a niember of the District of Columbia Judicial Nomination Commission), vacated as moot, 732 F.2d 181 (D.C. Cir. 1984).

9. For a partial listing of positions publicly taken by the Reagan administration, see Rosenberg, Congress's Prerogative Over Agencies and Agency Decisionmakers: The Rise and Demise of the Reagan Administration's Theory of the Unitary Executive, 57 GEO. WASH. L. REV. 627, 62930 (1989). The most conspicuous omission from Mr. Rosenberg's hist-an omission no doubt attributable to his focus on executive-legislative relations-is the Reagan administration's eminently correct suggestion that Supreme Court decisions do not and should not always bind the executive branch. See Meese, The Law of the Constitution, 61 Tul. L. Rev. 979 (1987); see also Harrison, The Role of the Legislative and Executive Branches in Interpreting the Constitution, 73 CORNELL L. REv. 371 (1988).

10. For example, the question of the constitutionality of law enforcement by "independent" agencies-that is, agencies whose top officials are not removable at the will of the President-never reached the Suprenie Court, and received only perfunctory treatment in the lower courts before 1988. See FTC v. American Nat'l Cellular, Inc., 810 F.2d 1511, 1513-14 (9th Cir. 1987) (permitting FTC commissioners to enforce federal law); SEC v. Warner, 652 F. Supp. 647, 648-49 (S.D. Fla. 1987) (allowing civil enforcement actions by the SEC). In 1988, the decision in Morrison v. Olson, 487 U.S. 654 (1988), validated by implication the proseeutorial activities of nost of these agencies as they are presently constituted. See SEC v. Blinder, Robinson \& Co., 855 F.2d 677, 681-82 (10th Cir. 1988) (invoking Morrison as authority for upholding the SEC's power to commence civil enforcement actions in federal court), cert. denied, 109 S. Ct. 1172 (1989). 
Circuit Court of Appeals decided Sakamoto v. Duty Free Shoppers, $L t d .{ }^{11}$ ending a lengthy squabble among gift merchants in the American territory of Guam. The facts of the case presented the unlikely but intriguing constitutional question of whether the appointinents clause applies to the chief executive of the Guamamian territorial government. As it turns out, lowever, the question was so unlikely that none of the parties or courts thought to ask it at any stage of the proceedings, and the case quietly faded into obscurity.

From the standpoint of formalists, who are generally unhappy with the federal courts' recent track record in separation of powers cases, ${ }^{12}$ this oversiglit may be something of a blessing. The questions lurking behind Sakamoto, lowever, are too important--botll substantively and historically-to be left unasked. Formalists who reflect carefully on the relationship between territories and the Constitution are likely to find themselves doubting, if they did not already doubt, the constitutional validity of institutions of territorial governance that have existed since the nation's founding. Moreover, the list of potentially troubling institutions includes the principal administrative devices that Congress has employed over the years to provide territorial inhabitants with some measure of self-determination-a goal whose normative appeal today goes unquestioned in polite company. Thus, formalists must seriously entertain the no doubt unappetizing possibility that democratic self-governance in the territories is unconstitutional. ${ }^{13}$

The subject of territorial governance has an important historical dimension as well. Those who inquire into the applicability of the Constitution's structural provisions to territorial officials will find themselves embarked on a long and arduous, but richly rewarding, journey through some long-forgotten crevasses of constitutional history. Altlough the question of the proper relationship between territories and the Constitution lias largely disappeared from the legal scene in modern times, it occupied mucli of the energy of the courts in the nineteenth and early twentietlı centuries. ${ }^{14}$ Participants in and observers of the modern

11. 764 F.2d 1285 (9th Cir. 1985), cert. denied, 475 U.S. 1081 (1986).

12. This is not to say that formalists did not have their moments in the sun. The Supreme Court's approach to separation of powers issues in the 1980s was inconsistent enough to please no one fully, see supra notes 1-4, and the executive branch was mostly on the formalists' side. Nonetheless, the functionalists clearly won the decade, at least in the courts and Congress, by TKO.

13. I do not find the conclusion especially troubling, but I doubt whether my reaction is representative of formalists as a class. For me, the problem with "self-governance" is that the "self" performing the "governance" is invariably a collective entity or polity. In reality, this means that some selves are governing other selves. Nonetheless, I will continue to use the term "selfgovernance" in its conventional sense, with all its positive modern connotations, notwithstanding my libertarian qualms.

14. "The status of American territories was once the premier constitutional question facing the Supreine Court, if interest in both legal circles and the general public is taken as a measure." 
revival of interest in separation of powers do themselves a disservice if they overlook this oft-ignored chapter of American constitutional history. Its lessons are consistently enlightening, often discomfiting, and more than occasionally entertaining.

My goal here is to bring forth both the analytical and historical insights that emerge from a close investigation of the peculiar institution of American territorial governance. Part I of this Article, however, opens the discussion on a somewhat discordant theoretical note by setting forth iny conception of fornalism. Readers who are numbed by the prospect of a conceptual analysis of formalism can-and should-simply skip directly to the more sprightly historical narrative beginning in Part II. Part II uses the peculiar facts of Sakamoto to introduce and illustrate the coinplex separation of powers issues raised by questions of territorial status. The discussion then highlights the unbridgeable distance between the formahist approach to these issues and the dominant historical and current doctrimal understandings of the respective roles of the political branches and the Constitution in structuring territorial governments. Part III pursues the historical enterprise in earnest, surveying and critically discussing the explicitly antiformalist constitutional history of the principal organs of territorial governance. This survey reveals that forinalism's deimise was the product of default as much as design; historically, forinalisin has not been so inuch rejected as ignored. Part IV then reflects on the consequences of formalism for territorial administration, suggesting that they need not be quite as dramatic_-or threateining-as they inay seem at first glance.

\section{I}

\section{A Terminological Prologue}

Whatever "formalism" and "functionalism" might mean in the abstract, ${ }^{15}$ they have becoine terms of art in discourse concernimg separation of powers. ${ }^{16}$ Formalists treat the Constitution's three "vesting"

Laughlin, The Application of the Constitution in United States Territories: American Samoa, A Case Study, 2 U. HAw. L REV. 337, 343 (1980-81) [hereinafter Laughlin, American Samoa]. In fact, one could fairly say that twice it was the premier constitutional question facing the Court: once at the turn of this century, when debate centered on the applicability of the Constitution to possessions acquired in the "imperialist" era, see Coudert, The Evolution of the Doctrine of Territorial Incorporation, 26 ColUM. L. REV. 823, 823 (1926), and once just prior to the Civil War, when debate concerned the power of Congress to prohibit slavery in the territories, see Dred Scott v. Sandford, 60 U.S. (19 How.) 393 (1857).

15. For an intriguing discussion of the former, see Schauer, Formalism, 97 YALE L.J. 509 (1988).

16. Other terms with much the same ineanings are sometimes employed. Professor Carter distinguishes between "evolutionary" and "de-evolutionary" approaches to the separation of powers, corresponding roughly to the distinction between functionalism and (originalist) formalism set forth below. See Carter, From Sick Chicken to Synar: The Evolution and Subsequent De-Evolution of the 
clauses ${ }^{17}$ as effecting a complete division of otherwise unallocated federal governmental authority among the constitutionally specified legislative, executive, and judicial imstitutions. Any exercise of governmental power, and any governmental institution exercismg that power, must either fit within one of the three formal categories thus established or find explicit constitutional authorization for such deviation. ${ }^{18}$ The separation of powers principle is violated whenever the categorizations of the exercised power and the exercising institution do not inatch and the Constitution does not specifically permit such blending. ${ }^{19}$

The formalist method is concededly easier to describe than to apply, because not all governmental activities are associated with only one particular institution. For example, Congress can resolve disputes concerning government contracts by passing private bills or by entrusting the dispute resolution to courts. The activity can thus be either legislative or

Separation of Powers, 1987 B.Y.U. L. REV. 719, 719-21. Professor Miller's distinction between pragmatic (functionalist) and neoclassical (formalist) approaches captures essentially the samc ideas. See Miller, Independent Agencies, 1986 Sup. CT. REv. 41, 52-54. I do not suggest that Professors Carter and Miller, or anyone else, would subscribe wholly to my particular version of the dichotomy, but we are all at least in the same ballpark.

17. U.S. CONST. art. I, $\$ 1$ ("All legislative Powers herein granted shall be vested in a Congress of the United States ...."); id. art. II, $\S 1$, cl. 1 ("The executive Power shall be vested in a President of the United States of America."); id. art. III, $\S 1$ ("The judicial Power of the United States, shall be vested in one suprene Court, and in such inferior Courts as the Congress may from time to time ordain and establish.").

18. See, e.g., Liberman, Morrison v. Olson: A Formalistic Perspective on Why The Court Was Wrong, 38 AM. U.L. REV. 313, 343 (1989) ("A formalist decision uses a syllogistic, definitional approach to determining whether a particular exercise of power is legislative, executive, or judicial. It assumes that all exercises of power inust fall into one of these categories . . . .").

19. It bears eniphasizing that formalisin does not call for adherence to some theoretically pure separation of legislative, executive, and judicial functions. Rather, it calls for adherence to the particular, theoretically "impure" structure of separation specified in the Constitution, with the threc traditional categories of functions and institutions used to answer questions not specifically addressed by the text. See generally Burns \& Markman, Understanding Separation of Powers, 7 PACE L. REV. 575, 578-85 (1987) (describing a formalist conception of separation of powers, with reference to explicit powers that do not fit neatly within the tripartite scheme). The Senate's power to try impeachments, U.S. CONST. art. I, $\S 3, \mathrm{cl} .6$, is perhaps the most conspicuous example of constitutionally sanctioned blending of functions and institutions: the power seems clearly judicial, but the Constitution specifically permits its exercise by a legislative organ.

The President's role in the lawmaking process may be an example of an explicitly authorized power that is neither legislative, executive, nor judicial. The American President's power to sign or veto legislation, $i d . \S 7$, cl. 2 , is not umique among chief executives, but it is not rcadily classified as an "executive" power. Lawmaking is, after all, the quintessential legislative activity. Thus, the Constitution's grant of lawmaking power to the President looks at first glance like a straightforward example of executive-legislative blending. The Constitution, however, vests "[a]ll legislative powers herein granted . . . in a Congress of the Urited States." Id. $\S 1$ (emphasis added). Hence, thc Constitution has declared, by definitional fiat, that no power vested in a federal institution other than Congress can be considered legislative. The President's lawinaling power thus appears to defy tripartite classification. (I am indebted to Bob Bennett for this insight.) Formalists can either stretch the definition of executive power to encompass the signing or vetoing of legislation, or, as I have done, sunply acknowledge that the Constitution determines when its own rules do and do not apply. 
judicial, depending upon which institution performs it. ${ }^{20}$ Similarly, certain political bodies can be simultaneously part of more than one governmental institution. One can imagine-and Congress lias on occasion created-bodies tliat perform botli judicial and executive functions, enjoying independence in tlie exercise of the former but answerimg to the President for the performance of the latter. ${ }^{21}$ The formalist, however, views these areas of overlap among the three constitutional functions and institutions as limited. Outside of these areas, and absent constitutional autliorization to the contrary, formalism maintams that eacli imstitution Inust exercise its correlative power and no otliers, without regard to the pragmatic usefulness or liarmlessness of having tle "wrong" institution exercise a power.

As I employ the term (and others are frec to einploy it differently), formalism is mextricably tied to both textualism and originalisin, altlough the three conccpts are logically distinct. Textualism declares that the meaning of the Constitution is to be found exclusively in the document's text and structure, and any inferences to be drawn therefrom. ${ }^{22}$ Originalism specifies the point in time and space at whicli the values of the relevant interpretative variables are to be determined; for purposes of this discussion, it is sufficient to fix that time and space as "the late eighteentli century in America."23 Formalism, at least in my hands, is an application of originalist textualism to questions of constitu-

20. Cf. Bowsher v. Synar, 478 U.S. 714, 749 (1986) (Stevens, J., concurring) ("[A]s our cases demonstrate, a particular function, like a chameleon, will often take on the aspect of the office to which it is assigned ...."); INS v. Chadha, 462 U.S. 919, 953 n.16 (1983) (Though his actions might "resemble 'legislative' action in some respects," "the Attorney General acts in his presumptively Art. II capacity when he administers the Immigration and Nationality Act.").

21. See O'Donoghue v. United States, 289 U.S. 516, 545-51 (1933) (Congress has the power to impose nonjudicial administrative functions on the District of Columbia courts). Note that while the Constitution specifically forbids legislative officials from simultaneously serving in other branches, U.S. CONST. art. I, $\S 6$, cl. 2, it contains no equivalent restriction on judicial officers who wish to serve also in the executive branch.

22. One can perfectly well imagine a self-proclaimed "formalist" insisting that the intentions of the framers or ratifiers of the Constitution should be added to-or substituted for-this hitany. It is indeed possible to come up with broader definitions of formalism that leave room for textualists and "intentionalists" alike. I have used a narrower definition purely for reasons of convemieuce. I am a textualist, not an intentionalist, and am understandably interested principally in describing and applying my own theory. To discuss my theory within the framework of a wider definition of formalism would require ine to speak of "formalism wedded to a textualist jurisprudence of original semantic meaning," which seeins to me reason enough not to do so.

23. I doubt whether public understanding of the language relevant to constitutional interpretation shifted significantly between 1787 and 1789. There inay, however, have been quite substantial shifts in the meanings or understandings of words between, for example, 1787 and 1987. That is why textualisin and originalism are distinct concepts. There is, in short, an inescapable temporal dimension to interpretation; a complete interpretative theory must not ouly specify the operable variables for the imterpretative enterprise, but mnst also specify the point in time and space at which the values of those variables will be set. See generally Lawson, In Praise of Woodenness, 11 Geo. Mason U.L. ReV. 21, 22 \& n.8 (Winter 1988). 
tional structure. Defined more precisely, formalism consists of a substantive principle of interpretation ("Resolve separation of powers questions using only the text, structure, and background of the Constitution, applying late eighteenth-century America as the locus of meaning for those interpretative variables") and a primary inference ("The vesting clauses divide otherwise unallocated federal governinental authority into three kinds of functions and fully distribute it among three distinct sets of institutions").

Formalism can usefully be contrasted with functionalism, its principal methodological competitor in the separation of powers arena. ${ }^{24}$ In its simplest formnlation, functionalism asks "whether the exercise of the contested function by one branch impermissibly intrudes into the core function or domain of [another] branch."25 In other words, the question of blending is treated as one of degree rather than, as with formalisin, one of kind. A different strand of functionalism begins with the (correct) observation that " $[t]$ he constitutional text addresses the powers only of the elected members of Congress, of the President as an individual, and of the [federal courts]."26 The Constitution does not speak of "branches" as such, nor does it discuss the institutions of government subordinate to the three named heads of authority. The functionalist thus infers that Congress is free to allocate authority as it pleases annong subordinate institutions (however formalists would characterize them), as long as the "overall character or quality"27 of the relationships between those institutions and the named heads of government is consistent with the latters' performance of their core functions. ${ }^{28}$

Functionalism is not the only possible alternative to formalism. ${ }^{29}$ In

24. It is possible (as evidenced by the fact that some people do it) to advocate formalism with regard to separation of powers questions, while adopting entirely different approaches to other kinds of constitutional issues. See M. PERrY, MORALITY, PolmTics, AND LAW 141 (1988) (arguing that a nonoriginalist approach may be applied to some constitutional provisions while an originalist approach is applied to others); Carter, The Supreme Court, 1987 Term-Comment: The Independent Counsel Mess, 102 HARv. L. REv. 105, 119-21 (1988) (distinguishing between the interpretative theories to be applied to the "Political Constitution" and to the "Natural Rights Constitution"). I have dealt with this problem by limiting formalism by definition to the spherc of separation of powcrs. Thus, in my lexicon, the phrase "formalism with regard to separation of powers questious" is redundant.

25. Krent, Separating the Strands in Separation of Powers Controversies, 74 VA. L. REv. 1253, 1255 (1988).

26. Strauss, Formal and Functional Approaches to Separation-of-Powers Questions-A Foolish Inconsistency?, 72 CORNELl L. REv. 488, 493 (1987).

27. Id. at 494.

28. See generally id. at $492-96$ (Professor Strauss defending his version of functionalism); Liberman, supra note 18, at 343 (explaining Strauss' position); Rosenberg, supra note 9, at 636-37 (advocating a position similar to Strauss').

29. For example, one might believe that the Coustitution should be read in whatever manner best accords with the current platform of one's favorite political party-a position that cynics might suggest is somewhat better represented among scholars than many of them are prepared to adinit. 
particular, the antiformalist decisions catalogued in Parts II and III do not necessarily embrace functionalism, at least not as functionalism is understood by its most prominent adherents. This Article does not attempt to defend formalism either as a descriptive theory of interpretation or as a normative theory of governmental decisionmaking. My reasons for avoiding any such tasks are straightforward: I do not do the former because I beheve that an adequate account of any interpretative theory must be einbedded in a inore general treatinent of episteinology, and I do not do the latter because I beheve that any normative proposition inust be derived froin a foundationally sound moral theory. ${ }^{30}$ Accordingly, iny aims here are descriptive and historical. I seek to examine the consequences of applying formalisin to the governance of territories and to bring to light soine important (or at least interesting) aspects of the history of the Supreme Court's rejection of formalism in this area. Persons who are looking for reasons to beconne formalists will, at least for now, have to look elsewhere.

\section{II}

\section{Formalism AND TERRITORIAL STRUCTURE}

The constitutional status of territories lias been at the center of some of the most famous and contentious cases in American constitutional history, such as the Insular Tariff Cases, ${ }^{31}$ Dred Scott v. Sandford, ${ }^{32}$ and Marbury v. Madison. ${ }^{33}$ This is improbable company for Sakamoto $v$.

30. I have elsewhere described at length some of the devices that legal scholars typically employ to avoid facing hard foundational questions of moral theory, see Lawson, The Ethics of Insider Trading, 11 HARV. J.L. \& PUB. POL'Y 727, 775-81 (1988), and could easily give an equally lengthy description of the devices typically used to avoid hard foundational questions of interpretative theory. I prefer to avoid such questions openly and directly.

31. For a fuller discussion of these eases, see infra text accompanying notes 93-118.

32. 60 U.S. (19 How.) 393 (1857).

33. 5 U.S. (1 Cranch) 137 (1803). Marbury is discussed at infra text accompanying notes 14351. Marbury raised questions about the constitutional status of judges in the District of Columbia, which might not readily be thought of as a territory. Indeed, the constitutional status of the District of Columbia is determined by a different clause of the Constitution than is the status of other "territories." Compare U.S. CoNST. art. I, $\S 8, \mathrm{cl} .17$ (giving Congress the power "[t]o exercise exclusive Legislation in all Cases whatsoever, over such District . . . as may . . . become the Seat of the Government of the Umited States" and over federal enclaves within states) with id. art. IV, § 3 , cl. 2 (giving Congress "Power to dispose of and make all needful Rules and Regulations respecting the Territory or other Property belonging to the United States"). The differing language of these clauses could conceivably have some significance with respect to the legitimacy of local legislatures, see infra text accompanying notes 284-317, but I know of no reason to think that it otherwise nuatters. If anything, the formalist case against the traditional institutions of territorial (self-) governance is strongest with respect to the District of Columbia, since, unlike the original territories for whom statehood was imminent, the District cannot attain statehood absent a constitutional amendnient. (Note that the Constitution does not distinguish-as Congress currently does-among territories, trust territories, and coinmonwealths. The document provides for only four categories of politieal entities: the federal government, state governments, territories, and the District of 
Duty Free Shoppers, Ltd. ${ }^{34}$ This is not to say that Sakamoto was unimportant. It was in fact the culmination of a hard-fought struggle over the Guamamian macadamia nut candy monopoly. But while the struggle was (in its own way) epic, none of the participants saw the case as raising any questions of separation of powers, much less any momentous ones. Nonetheless, the questions implicit in Sakamoto make the case an ideal vehicle for airing some significant issues of constitutional structure.

\section{A. Of Monopolies and Macadamia Nuts}

Guam, one of the Mariana Islands, has been an American possession since it was ceded to the United States by Spam in 1899.35 Since 1950 , it has been administered by a civilian territorial government enjoying considerable local autonomy granted by Congress, ${ }^{36}$ including specifically the power to impose "royalties for franchises, privileges, and concessions." ${ }^{\prime 37}$ The territorial government lias used that power to raise revenues for airport improvements by auctioning off monopolies on the sale and delivery of goods at the Guam International Airport. ${ }^{38}$

Plamtiff Sakamoto and defendant Duty Free Shoppers, Limited ("DFS") sold gift merchandise in Guam, with Sakamoto's principal product evidently being Hawaiian Host inacadamia nut candies. ${ }^{39}$ The rival gift merchants competed primarily for the business of Japanese tourists, "who purchase gifts or 'o1myage' to carry back to Japan."40 The Japanese are an exigent clientele who "expect and deinand that their gift purchases be delivered to then at the airport so that they will not be inconvemienced during their vacation." ${ }^{11}$ Hence, the right to deliver goods sold elsewhere on the island to departing passengers at the Guam International Airport Terminal is of great importance to merchants competing for this vital segment of the tourist trade.

Columbia. The congressional designations thus have international law consequences, but no domestic constitutional significance.)

34. 475 U.S. 1081 (1986), denying cert. to 764 F.2d 1285 (9th Cir. 1985).

35. See 48 U.S.C. $\S 1421$ (1988) (defining the territory to be known as "Guam"); Ngiraingas v. Sanchez, 110 S. Ct. 1737, 1740 (1990) (citing Treaty of Paris, Dec. 10, 1898, United States-Spain, art. II, 30 Stat. 1754, 1755, reprinted in 11 TREATIES AND OTHER INTERNATIONAL AgREEMENTS OF THE UNITED STATES OF AMERICA 1776-1949, at 615, 616 (C. Bevans ed. 1974)).

36. The legislative power of the Guamanian government extends "to all subjects of legislation of local application." 48 U.S.C. $\$ 1423 \mathrm{a}$ (1988).

37. Id.

38. See infra note 43.

39. Brief for Respondents Guam Airport Authority and Duty Free Shoppers, Ltd. in Opposition to Petition for Writ of Certiorari at A-19, Sakamoto v. Duty Free Shoppers, Ltd., 475 U.S. 1081 (1986) (No. 85-552).

40. Sakamoto v. Duty Free Shoppers, Ltd., 764 F.2d 1285, 1286 (9th Cir. 1985), cert denied, 475 U.S. 1081 (1986).

41. Petition for a Writ of Certiorari to the Umited States Court of Appeals for the Ninth Circuit at 3, Sakamoto, 475 U.S. 1081 (No. 85-552). 
Since 1975, the airport terminal has been under the direet control of the Guam Airport Authority ("GAA"), an instrumentality of the territorial Government of Guam. ${ }^{42}$ In 1978, the GAA publicly sought bids on a fifteen-year exclusive concession for the sale and dehvery of gift iteins at the terminal..$^{43}$ DFS demonstrated the importance of airport delivery rights by submitting a winning bid of more than $\$ 140,000,000 .^{44}$

Following an mipressive series of atteinpts by Sakamoto to circumvent the exclusive concession, which led to an equally impressive series of warning letters from the GAA, ${ }^{45}$ Sakamoto filed suit agamst DFS, the GAA, and the Government of Guam, seeking invalidation of the franchise provision granting exclusive terminal dehvery rights to DFS. When the case reached the Ninth Circuit Court of Appeals, the challenge to the provision was essentially twofold. First, Sakamoto argued that the dehvery restriction violated the dormant commerce clause, ${ }^{46}$ a claim that was correctly rejeeted by the Ninth Circuit for reasons that are of only tangential concern here. ${ }^{47}$ Second, Sakamoto alleged that the concession

42. Sakamoto v. Duty Free Shoppers, Ltd., 613 F. Supp. 381, 384 (D. Guam 1983), affd, 764 F.2d 1285 (9th Cir. 1985), cern. denied, 475 U.S. 1081 (1986). Prior to 1975, the terminal was directly operated by the Government of Guam. Id.

43. Id. at 384-85. The Government of Guam first granted an exclusive concession in 1967, id. at 384, covering airport sales but not deliveries of goods, Brief for Plaintiffs-Appellants at 4, Sakamoto, 764 F.2d 1285 (No. 84-1587). Exclusive delivery rights were added when the concession was assigned to DFS by the original grantee in 1972. Id.

44. See Sakamoto, 613 F. Supp. at 385.

45. Initially, the procedure was as follows: Sakamoto sold the merchandise, accepted payment, and then cheeked it in for the customer at the airport. The airlines discontinued this practice in 1976 when DFS pointed out that the practice violated Federal Aviation Administration regulations. Sakamoto then had his employees simply deliver the merchandise to customers at the airport check-in counters, in open defiance of the exclusive franchise. The GAA put a halt to this operation in 1977. Next, Sakamoto tried delivering the goods to the departing customers' hotels, loading the goods onto tour buses, and then having his employees carry the goods from the buses to the check-in counters. In 1979 the GAA again instructed Sakamoto to stop making terminal deliveries. Sakamoto's last-diteh effort was to pay the tour agents and bus drivers to carry the merchandise into the terminal for the customers. The GAA was not amused and in 1980 issued what became the final warning letter. Id. at 385-86.

46. Try as I might, I cannot find a dormant commerce clause in the Constitution. Cf. U.S. ConsT. art. I, \& 8, cl. 3 ("The Congress shall have Power ... To regulate Commerce with foreign Nations, and annong the several States, and with the Indian Tribes ....."). The Supreme Court is either more perceptive or less fastidious than I. See generally Tyler Pipe Indus., Inc. v. Washington State Dep't of Revenue, 483 U.S. 232, 259-65 (1987) (Scalia, J., concurring in part and dissenting in part) (criticizing the Court's "negative commerce clanse" jurisprudence); Redish \& Nugent, The Dormant Commerce Clause and the Constitutional Balance of Federalism, 1987 DukE L.J. 569 (arguing that the donnant commerce clause has no textual basis in the Constitution and is also unsupported by nontextual theory).

47. The majority held that the donnant commerce clause has no application to acts of the Guamanian government. Sakamoto, 764 F.2d at 1286-88. This holding is correet. The dorinant commerce clause doctrine was invented by courts because of the perceived tension between congressional power to regulate interstate commerce and the independent regulatory authority of state governments. Guam, unlike the states, has only the regulatory authority specifically conferred on it by Congress. See United States v. Wheeler, 435 U.S. 313, 321 (1978). It makes no inore sense 
agreement violated the federal antitrust laws. ${ }^{48}$ The principal defense proffered against this claim was the antitrust immunity typically enjoyed by agencies or instrnmentalities of the federal government. And thereby hangs our tale.

It is well-settled that the antitrust laws do not apply to federal agencies or instrumentalities. ${ }^{49}$ It is also well-settled that territorial governments like Guain's are "entirely the creation of Congress,"so which has "general and plenary"51 authority over the territories. Congress has passed statutes granting Guam substantial powers of self-government, ${ }^{52}$ but that is purely a matter of legislative grace; the territory " "has no inherent right to govern itself." "53 Given this dependence on congressional authorization, the Supreme Court has characterized territorial governments as " "agenc[ies] of the federal government." "54 The defendants in Sakamoto had no trouble completing the syllogism: If the Government of Guam is a federal agency, and if federal agencies are entitled to immunity from the antitrust laws, then the Guamairian government's creation of an exclusive franchise must enjoy antitrust inımunity. The District Court, ${ }^{55}$ the Court of Appeals, ${ }^{56}$ and the Solicitor General ${ }^{57}$ all readily accepted this syllogisn. The Supreme Court denied certiorari, ${ }^{58}$ and the case disappeared.

to apply the dormant commerce clause to Guam than it does to apply it to the Federal Reserve Board or the Securities and Exchange Commission. Nor has Congress declared by statute that the dormant commerce clause doctrine is apphicable to Guam. See 48 U.S.C. $\S 1421$ b(u) (1988) (listing constitutional provisions applicable to Guam, but not mentioning the commerce clause).

48. See 15 U.S.C. $\$ \S 1-3$ (1988).

49. See Umited States v. Cooper Corp., 312 U.S. 600, 606 (1941) (dictum); Jet Courier Servs., Inc. v. Federal Reserve Bank, 713 F.2d 1221, 1228 (6th Cir. 1983); Sea-Land Serv., Inc. v. Alaska R.R., 659 F.2d 243, 246 (D.C. Cir. 1981), cert. denied, 455 U.S. 919 (1982).

50. Wheeler, 435 U.S. at 321.

51. Late Corp. of the Church of Jesus Christ of Latter-Day Saints v. United States, 136 U.S. 1, 42 (1890).

52. See Organic Act of Guam, cl. 512, 64 Stat. 384 (1950) (codified as aniended at 48 U.S.C. $\S \S 1421-24$ (1988)); Guam Elective Governor Act, Pub. L. No. 90-497, 82 Stat. 842 (1968) (codifled as anended at 10 U.S.C. $\S 335$ (1988), 48 U.S.C. $\$ \S 1421 \mathrm{a}-1421 \mathrm{~d}, 1421 \mathrm{f}, 1422-1422 \mathrm{~d}, 1423 \mathrm{~b}, 1423 \mathrm{~h}-$ $1423 \mathrm{i}(1988))$. Congress has also authorized adoption of a Guanianian constitution. See Act of Oct. 21, 1976, Pub. L. No. 94-584, 90 Stat. 2899 (codified as amended at 48 U.S.C. § 1391 note (1988)).

53. Ngiraingas v. Sanchez, 858 F.2d 1368, 1371 n.1 (9th Cir. 1988) (quoting Commonwealth of N. Mariana Islands v. Atalig, 723 F.2d 682, 687 (9th Cir.), cert. denied, 467 U.S. 1244 (1984)), affd, 110 S. Ct. 1737 (1990). Congress retains both the statutory and inherent power to annul legislative acts of the territorial government. See 48 U.S.C. $\S 1423 i$ (1988); National Bank v. County of Yankton, 101 U.S. 129, 133 (1880) (Congress has "full and complete legislative authority over the people of the territories and all the departments of the territorial governments").

54. Wheeler, 435 U.S. at 321 (quoting Domenech v. National City Bank of New York, 294 U.S. 199, 204-05 (1935)).

55. See Sakamoto, 613 F. Supp. at 386-88.

56. See Sakamoto, 764 F.2d at 1288-89.

57. See Brief for the Umited States as Amicus Curiae at 10-12, Sakamoto, 475 U.S. 1081 (No. 85-552).

58. Sakamoto, 475 U.S. 1081. 
When it disappeared, it took with it an unposed problem of remarkable dimension. The appointments clause of the Constitution provides that the President

shall nominate, and by and with the Advice and Consent of the Senate, shall appoint Ambassadors, other public Ministers and Consuls, Judges of the supreme Court, and all other Officers of the United States, whose Appointments are not lerein otherwise provided for, and which shall be estabhished by Law: but the Congress may by Law vest the Appointinent of such inferior Officers, as they think proper, in the President alone, in the Courts of Law, or in the Heads of Departments. ${ }^{59}$

The Constitution does not tell us which of the millions of federal employees rise to the level of "officers of the United States," ments must conform to this clause. ${ }^{61}$ The Supreme Court in Buckley v. Valeo $^{62}$ was surely nonetheless correct to include as officers "any appointee[s] exercising significant authority pursuant to the laws of the United States."63 The responsibilities of the territorial governor of Guam include "the faithful execution of the laws of Guam and the laws of the United States applicable in Guam."64 By any reasonable definition, that makes him an "officer of the United States," who thus inust be appointed in full conformity with the appoimtinents clause. The point was recognized by the 1950 Organic Act creating the Government of Guam, ${ }^{66}$ which originally provided that the governor would be "appointed by the President, by and with the advice and consent of the Senate." 67

In 1968, however, the Orgamic Act was amended by the Guam Elective Governor Act, which provided that the office of governor (and the newly created office of heutenant governor) was to be filled through pop-

59. U.S. CoNST. art. II, $\S 2$, cl. 2. The only officers whose appointments are "otherwise provided for' are the Vice President, see id. amend. XII, the officers of the militia, see id. art. I, $\S 8$, cl. 16, and (if they are properly viewed as "Officers of the Umited States") the officers of the House and Senate, see id. § 2, cl. 5; id. § 3, cl. 5.

60. Cf. Buckley v. Valeo, 424 U.S. 1, 126 n.162 (1976) (per curiam) (" 'Officers of the United States' does not include all employees of the United States . . . Employees are lesser functionaries subordinate to officers of the United States.").

61. Cf. United States v. Germaine, 99 U.S. 508, 510 (1879) ("That all persons who can be said to hold an office under the government about to be established under the Constitution were intended to be included within one or the other of these modes of appointment there can be but hittle doubt.").

62. 424 U.S. 1 (1976).

63. Id. at 126. In other words, an employee of the United States is an officer subject to the appointments clause if she is important enough to be subject to the appointments clause. Circular, perhaps, but serviceable nonetheless.

64. 48 U.S.C. $\$ 1422$ (1988) (emphasis added).

65. See text accompanying notes 70-74.

66. Orgamic Act of Guan, ch. 512, 64 Stat. 384 (1950) (codified as anended at 48 U.S.C. $\S \S 1421-24$ (1988)).

67. Id. $\S 6(\mathrm{a}), 64$ Stat. at 386 . 
ular election. ${ }^{68}$ Since this election procedure does not conform to the appointments clause, it seems that the governor of Guam-and by necessary imphication his subordinates-can no longer properly be charged with executing the laws of the Umited States. But if no Guamaman officials are empowered to execute the laws of the Umited States, how can the Government of Guam be a federal agency? Since the antitrust immumity of the GAA's grant of an exclusive concession was upheld by the court of appeals solely on the strength of an agencies-are-immune-andGuam-is-an-agency syllogism, a full assessment of the vahdity of DFS's monopoly on airport macadamia nut candy dehveries requires an inquiry into the apphication of the appointments clause to Guamanian officials. ${ }^{69}$

\section{B. Territorial Executives and the Appointments Clause}

\section{The Formalist Answer}

To a formalist, it seems obvious that the appointments clause applies to territorial officials. The clause itself is perfectly general: its plain meaning is that anyone who is an officer of the United States must take office through one of the specified modes of appointment. ${ }^{70}$ Territorial officials charged with executing federal law in their federally governed territories seem indisputably to be federal officers.

Of course, not all persons playing a significant role in the enforcement of federal statutes must necessarily be officers of the United States. From the time of the nation's founding, state officials have often been called upon to implement federal statutes, ${ }^{71}$ but those officials are not by virtue of that fact subject to the appointments clause. State officials, however, draw their powers from an independent sovereign entity within a system of dual governmental sovereignty; their authority is part of the background agamst which all federal authority is exercised. Just as state judges can adjudicate federal causes of action without becoming constitutional "judges of inferior courts,"72 state officials can execute federal law

68. Pub. L. No. $90-497, \S 1,82$ Stat. 842,842 (1968) (codified as amended at 48 U.S.C. $\S 1422$ (1988)).

69. One could, of course, decide Sakamoto without making this inquiry by reasoning that even if Guam is not technically a federal agency, it is sufficiently agency-like to escape the coverage of the antitrust laws. But that would be cheating.

70. The applicable mode depends upon the status of the officer. Inferior officers can be appointed by the President, courts, or department heads without Senate confirmation, while primcipal officers inust be appointed by the President with the Senate's advice and consent. U.S. CONST. art. II, $\S 2, \mathrm{cl} .2$. Determining whether the Guamanian governor is a principal or inferior officer is unnecessary, as he is not presently appointed in conformity with any of the prescribed modes.

71. See Warren, Federal Criminal Laws and the State Courts, 38 Harv. L. Rev. 545, 554 (1925).

72. The phrase is taken from article III of the Constitution: "The Judges, both of the supreine and inferior Courts, shall hold their Offices during good Behavior ...." U.S. CONST. art. III, \&1. 
without becoming "officers of the United States."73 Not so with territorial officials, who owe their existence to and derive all their powers front federal law. ${ }^{74}$ Territorial officials appear unmistakably to be officers of the United States, who nuust be appointed in accordance with the terms of the appointments clause.

No other provision of the Constitution casts doubt on this straightforward analysis. While the Constitution specifically authorizes Congress to "Inake all needful Rules and Regulations respecting the Territory or other Property belonging to the United States,"75 this power no nuore trumps the appointnients clause than do any of Congress' other plenary powers, such as its power to regulate federal elections ${ }^{76}$ or to pass all laws "necessary and proper" to execute its enumerated powers. ${ }^{77}$ All are subject to the Constitution's structural constraints. ${ }^{78}$ One could argue that the congressional power to admit new states ${ }^{79}$ imphes the power to create "probationary" governments in the territories, but this at

73. The phrase is from the appointments clause. See supra note 59.

74. This is true even when the relevant federal law is the organic legislation permitting their election. In a sense, officials in states admitted subsequent to ratification of the Constitution also owe their existence to federal legislation-naniely, the congressional statutes authorizing the admission of new states. See generally U.S. CoNST. art. IV, § 3, cl. I (authorizing Congress to admit new states). However, under the Constitution's system of dual sovereignty, the creation of a new state has different consequences than the creation of a new territory. States are independent constitutional sovereigns; their status as states may depend on congressional legislation but their sovereign powers after formation do not. Territories, by contrast, have no independent sovereignty; their status and powers derive solely from federal law. See Cimcinnati Soap Co. v. United States, 301 U.S. 308, 317 (1937); Grafton v. Umited States, 206 U.S. 333, 354-55 (1907); supra text accompanying notes 50-54.

The place of Native American tribes in this constitutional scheme is a fascinating question that I am unequipped to answer. For an illuminating exploration of some of the important issues raised around tribal status, see Resnik, Dependent Sovereigns: Indian Tribes, States, and the Federal Courts, 56 U. CHI. L. REv. 671 (1989).

The most difficult problem for formalists in this area is the execution of federal law through private lawsuits. Where the relevant statute creates a rccognizably private right, its enforcement through citizen suits does not constitute execution of the laws in the constitutional sense. But where the "right" being enforced is not plausibly private, then it secms at least worthy of discussion whether Congress can constitutionally confer enforcement authority on private parties, thereby making them "private attorneys general." A clear exaniple of (on formalist premises) unconstitutional public enforcement by private parties is qui tam litigation, in which private parties are authorized by statute to bring civil penalty actions on behalf of the United States. But see Caminker, The Constitutionality of Qui Tam Actions, 99 YALE L.J. 341, 374-80 (1989) (offering a functionalist defense of qui tam statutes against the formalist appointments clause challenge).

75. U.S. CoNST. art. IV, $\S 3$, cl. 2 (the "territories clause").

76. See id. art. I, $\S 4$, cl. 1; id. art. II, $\S 1$, cl. 4.

77. Id. art. I, $\S 8$, cl. 18.

78. See Buckley v. Valeo, 424 U.S. 1, 132 (1976) (per curiant) ("We see no reason to believe that the authority of Congress over federal election practices is of such a wholly different nature from the other grants of authority to Congress that it may be employed im such a manner as to offend well established constitutional restrictions stemming from the separation of powers."); see also infra text accompanying notes 292-94.

79. See U.S. CoNST. art. IV, § 3 , cl. 1. 
most would establish that the territories clause ${ }^{80}$ is superfluous, not that territorial governments are immune from constitutional prolibitions.

The First Congress appears to have shared this formalist understanding of the appointments clause. The Northwest Ordinance of $1787^{81}$ provided for appointinent and removal by Congress of various territorial officials, mcluding a governor. ${ }^{82}$ One of the first acts of Congress following ratification of the Constitution was to amend the Northwest Ordinance "so as to adapt the same to the present Constitution of the Umited States."83 One of the four amendinents declared that "the President shall nominate, and by and with the advice and consent of the Senate, shall appoint all officers which by the said ordinance were to have been appoimted by the United States in Congress assembled."84 Thus, the First Congress evidently felt the need to ensure that the appoimtment of territorial officials compled with the cominands of the apponitments clause im order to "adapt" the Northwest Ordinance to the Constitution.

This construction of the appointments clause reigned for more than 150 years in practice and lias never been exphcitly repudiated in theory. Prior to 1947, every statute creating a territorial governinent provided for direct control by the executive branch, usually through a presidentially appointed governor. ${ }^{85}$ The first clear deviation from this practice

80. See supra note 75 and accompanying text.

81. An Ordinance for the Government of the Territory of the United States north-west of the river Ohio (1787), reprinted at 1 Stat. 50, 51 n.(a) (1789).

82. Id.

83. Act of August 7, 1789, ch.8, 1 Stat. 50, 51 .

84. Id. $\S 1,1$ Stat. at 53 . Other amendments specified that the territorial secretary was to act in the governor's absence, id. $\$ 2,1$ Stat. at 53 , all required reports were to be filed with the President, id. $\S 1,1$ Stat. at 52-53, and the President rather than Congress was to exercise the removal power, $i d$. $\S 1,1$ Stat. at 53 .

85. See Act of May 26, 1790, ch. 14, 1 Stat. 123 (Tennessee, then known only as the Territory of the United States, south of the river Ohio); Act of Apr. 7, 1798, ch. 28, § 3, 1 Stat. 549, 550 (Mississippi); Act of May 7, 1800, ch. 41, § 3, 2 Stat. 58, 59 (Indiana); Act of Mar. 26, 1804, ch. 38, $\S \S 2,12,2$ Stat. 283, 283, 287 (Orleans and Louisiana); Act of Jan. 11, 1805, ch. 5, § 3, 2 Stat. 309, 309 (Michigan); Act of Feb. 3, 1809, ch. 13, § 3, 2 Stat. 514, 515 (Illinois); Act of June 4, 1812, ch. 95, $\S 2,12,2$ Stat. 743, 744, 746 (Missouri); Act of Mar. 3, 1817, ch. 59, § 2, 3 Stat. 371, 372 (Alabama); Act of Mar. 2, 1819, ch. 49, $\S \S 3,9,3$ Stat. 493, 494, 495 (Arkansas); Act of Mar. 30, 1822, ch. 13, §§ 2, 8, 3 Stat. 654, 655, 657 (Florida); Act of Mar. 3, 1823, ch. 28, §§ 2, 10, 3 Stat. 750, 750-51, 753 (Florida); Act of Apr. 20, 1836, ch. 54, §§ 2, 11, 5 Stat. 10, 11, 14 (Wisconsin); Act of June 12, 1838, ch. 96, §§ 2, 11, 5 Stat. 235, 236, 238 (Iowa); Act of Aug. 14, 1848, ch. 177, §§ 2, 11, 9 Stat. 323, 324, 327 (Oregon); Act of Mar. 3, 1849, ch. 121, §§ 2, 11, 9 Stat. 403, 404, 407 (Minnesota); Act of Sept. 9, 1850, ch. 49, §§ 3, 12, 9 Stat. 446, 447, 450 (New Mexico); Act of Sept. 9, 1850, ch. 51, §§ 2, 11, 9 Stat. 453, 453, 456 (Utah); Act of Mar. 2, 1853, ch. 90, §§ 2, 11, 10 Stat. $172,173,176$ (Washington); Act of May 30, 1854, ch. 59, $\$ \S 2,12,20,30$, 10 Stat. 277, 278, 281, 284, 288 (Nebraska and Kansas); Act of Feb. 28, 1861, ch. 59, §§ 2, 11, 12 Stat. 172, 172, 175 (Colorado); Act of Mar. 2, 1861, ch. 83, $\S \S 2,11,12$ Stat. 209, 210, 213 (Nevada); Act of Mar. 2, 1861, ch. 86, §§ 2, 11, 12 Stat. 239, 239-40, 242 (Dakota); Act of Feb. 24, 1863, ch. 56, § 2, 12 Stat. 664, 665 (Arizona); Act of Mar. 3, 1863, ch. 117, $\S \S 2,11,12$ Stat. 808, 809, 812 (Idaho); Act of May 26, 1864, ch. 95, $\S \S 2,11,13$ Stat. 85, 86, 90 (Montana); Act of July 25, 1868, ch. 235, $\S ~ 2,11$, 
was a 1947 amendment to the Organic Act of Puerto Rico authorizing popular gubernatorial elections ${ }^{86}$ - a practice extended by statute $\dot{m} 1968$ to Guam $^{87}$ and to the Virgin Islands, ${ }^{88}$ and by administrative order in 1977 to Sanioa. ${ }^{89}$ None of these anjendments were accompanied by

15 Stat. 178, 178, 181-82 (Wyoming); Act of May 17, 1884, ch. 53, §§ 2, 9, 23 Stat. 24, 24, 26 (Alaska); Act of May 2, 1890, ch. 182, $\S \S 2,14,26$ Stat. 81, 82, 88 (Oklahoma); Act of Apr. 12, 1900, ch. 191, § 17, 31 Stat. 77, 81 (temporary civil government for Puerto Rico); Act of Apr. 30, 1900 , ch. $339, \S \S 66,67,31$ Stat. 141, 153 (Hawaii); Act of June 6, 1900, ch. 786, $\$ \$ 2,10,31$ Stat. 321, 321-322, 325 (Alaska); Act of Mar. 2, 1901, ch. 803, 31 Stat. 895, 910 (military government for the Philippines); Act of July 1, 1902, ch. 1369, § 1, 32 Stat. 691, 691-92 (temporary civil government for the Philippines); Panama Canal Act, ch. 390, §§ 4, 7, 37 Stat. 560, 561, 564 (1912) (Pawama Canal Zone); Act of Aug. 29, 1916, ch. 416, § 21, 39 Stat. 545, 552 (permauent government for the Plilippines); Act of Mar. 2, 1917, ch. 145, $\S 12,39$ Stat. 951, 955 (permauent government for Puerto Rico); Act of Feb. 20, 1929, ch. 281, $\S$ (c), 45 Stat. 1253, 1253 (codified at 48 U.S.C. $\S 1661$ (c) (1988)) (Eastern Samoa); Organic Act of the Virgin Islands of the Umited States, ch. 699, $\$ 20,49$ Stat. 1807, 1812 (1936) (Virgin Islands); see also Act of June 30, 1954, ch. 423, § 1, 68 Stat. 330, 330 (codified at 48 U.S.C. $\$ 1681$ (a) (1988)) (Trust Territory of the Pacific Islands).

The one possible exception during this period was the District of Columbia government from 1812 through 1871. When Congress mitially incorporated the city of Washington, Congress provided for a presidentially appointed mayor. See Act of May 3, 1802, cl. 53, § 5, 2 Stat. 195, 196. The city's charter was amended in 1812 to provide for the election of the mayor by the popularly elected members of local boards, see Act of May 4, 1812, ch. 75, $\$ \S 1,3,2$ Stat. 721, 721-23, and amended again in 1820 to provide for direct popular election of the mayor, see Act of May 15, 1820, ch. $104, \S 3,3$ Stat. 583, 584. This regime lasted until 1871 , when the city was reconstituted as a territory with a presidentially appointed governor. See Act of Feb. 21, 1871, ch. 62, § 2, 16 Stat. 419,419 . Note, however, that the 1812 statute only authorized the elected mayor to "see that the laws of the corporation be duly executed." Act of May 4, 1812, ch. 75, § 3, 2 Stat. 721, 723 (emphasis added). This wording stands in marked contrast to the typical nineteenth-century charge to territorial governors to "take care that the laws be faithfully executed," see, e.g., Act of Mar. 26, 1804, ch. 38, § 2, 2 Stat. 283, 283 (Orleans and Louisiana) (emphasis added), presumably meaning all locally applicable federal laws, and the inore exphicit typical twentieth-century charge to "be responsible for the faithful execution of the laws of Porto Rico and of the United States applicable in Porto Rico." Act of Mar. 2, 1917, ch. 145, § 12, 39 Stat. 951, 955 (emphasis added). (The 1820 charter amendment contained no general declaration of the mayor's executive power.) Thus, Congress may not have thought it was giving the elected mayor of the District of Columbia the authority to execute the laws of the Umited States. But see text accompanying notes 258-59 (arguing that all territorial laws are laws of the United States for purposes of article II).

The reader may have noticed the unusual spelling of Puerto Rico ("Porto Rico") in portions of the previous paragraph. This was the original spelling, which Congress changed to its current form in 1932. See Act of May 17, 1932, ch. 190, 47 Stat. 158; Laughlin, American Samoa, supra note 14, at 343 n.26. Similarly, Arkansas was called "Arkansaw" when it first became a territory. In this Article, I use the arcliaic spellings only when quoting material that employs thein.

86. See Act of Aug. 5, 1947, ch. 490, $\S 1,61$ Stat. 770, 770-71. This provision was repealed when Puerto Rico's constitution took effeet. See Act of July 3, 1950, ch. 446, § 5, 64 Stat. 319, 320; see also P.R. CoNST. art. IV, $\S 1$ (providing for an elected governor).

87. See Guam Elective Governor Act, Pub. L. No. 90-497, § 1, 82 Stat. 842, 842 (1968) (codified as amended at 48 U.S.C. $\S 1422$ (1988)).

88. See Virgin Islands Elective Governor Act, Pub. L. No. 90-496, § 4, 82 Stat. 837, 837 (1968) (codified as amended at 48 U.S.C. $\S 1591$ (1988)).

89. See AM. SAMOA REV. CONST. art. IV, § 2. Samoa is governed administratively by the Secretary of the Interior, see 48 U.S.C. \$ 1661(c) (1988); Exee. Order No. 10,264, 16 Fed. Reg. 6419 (1951), reprinted in 48 U.S.C. $\$ 1662$ note (1988), who approved and promulgated a Samoan constitution effective as of July 1, 1967. See AM. SAMOA REv. ConsT. art. V, §11. The constitutional provision mandating an elected governor (who has authority to execute Umited States 
explicit discussion-nor, evidently, by congressional recognition-of their constitutional implications for the appointments clause. ${ }^{90}$

Case law, if one is concerned about such things, also does not specifically hold that the appointinent of territorial officials need not comport with the appointments clause; ${ }^{91}$ at least, I am not aware of any case directly addressing the issue. ${ }^{92}$ Nonetheless, while the federal courts have not ruled on the precise issue posed by Sakamoto, the Supreine Court has described at length its views on the proper approach to questions of territorial governance. Here the formalist juggernaut comes to a crashing lialt, as the Court's chosen approach is far removed froin formalism-and indeed from any other recognizable constitutional theory.

laws, see AM. SAMOA CODE ANN. § 4.0111(a) (1981)), was promulgated by the Secretary in 1977. See Order No. 3009, 42 Fed. Reg. 48,398 (1977).

90. The legislative histories of the statutes pertaining to Puerto Rico, Guam, and the Virgin Islands do not mention the issue. See S. REP. No. 422, 80th Cong., 1st Sess. (1947) (Puerto Rico); H.R. REP. No. 455, 80th Cong., 1st Sess. (1947) (Puerto Rico); 93 CoNG. REC. 7076-79, 10,402-03 (1947) (Puerto Rico); H.R. REP. No. 1521, 90th Cong., 2d Sess. (1968) (Guam); S. Rep. No. 1704, 89th Cong., 2d Sess. (1969) (Guam); H.R. REP. No. 1520, 89th Cong., 2d Sess. (1966) (Guam); 114 CoNG. REC. 17,438-45, 23,044-47 (1968) (Guam); 112 CoNG. REC. 10,545-51, 25,977-79 (1966) (Guam); H.R. REP. No. 1522, 90th Cong., 2d Sess. (1968) (Virgin Islands); S. REP. No. 1705, 89th Cong., 2d Sess. (1966) (Virgin Islands); H.R. REP. No. 1519, 89th Cong., 2d Sess. (1966) (Virgin Islands); 114 CoNG. REC. 17,445-50, 23,047-50, 23,692 (1968) (Virgin Islands); 112 CoNG. REC. $10,551-53,25,979-81$ (1966) (Virgin Islands).

91. The relevance of precedent depends upon the question asked. If the object is to predict how courts will decide cases or to influence their decisions, then precedent is an important factor to consider. If the goal is to determine what the Constitution actually says about territorial governance, however, then court decisions-like executive and congressional decisions (including those of the First Congress)-mnst stand or fall on their merits. Cf. Lawson, AIDS, Astrology, and Arline: Towards a Causal Interpretation of Section 504, 17 HofsTrA L. Rev. 237, 313 (1989) (making the same point regarding statutory interpretation).

A more difficult question is whether and to what extent case law is relevant if the goal is to prescribe correct constitutional decisions. Any time a court (or other government actor) relies on an mcorrect precedent in statutory or constitutional cases, it in essence allows a past judicial decision to amend the relevant text. The constitutionally specified procedures for passing (and, impliedly, amending) statutes, see U.S. CoNST. art. I, § 7, cl. 2, or amending the Constitution itself, cither through the procedures of article $\mathrm{V}$, see id. art. $\mathrm{V}$, or direct national referenda, see Amar, Philadelphia Revisited: Amending the Constitution Outside Article V, 55 U. CH1. L. REV. 1043 (1988), do not give an explicit role to the judiciary. Thus, such a use of precedent arguably usurps the structural prerogatives of the President, the Congress, the states, and the people. On the other hand, it is possible that "[t]he judicial Power of the United States," U.S. CONST. art. III, \& 1, vested in the federal courts, imcludes sone power to give determinative effect to prior decisions. See $\mathbf{R}$. Bork, The Tempting of America: The Polttical Seduction of the Law 157 (1990); Amar, Our Forgotten Constitution: A Bicentennial Comment, 97 YALE L.J. 281, 294 n.51 (1987). With this view, while a judicial decision contrary to the governing text might be illegitimate, the error once made acquires an authoritative status "by a sort of intellectual adverse possession." Tyler Pipe Indus. v. Washington State Dep't of Revenue, 483 U.S. 232, 265 (1987) (Scalia, J., concurring in part and dissenting in part).

92. The removal of territorial judges has been the subject of some discussion. See McAllister v. United States, 141 U.S. 174, 179-85, 189-90 (1891); United States ex rel. Goodrich v. Guthrie, 58 U.S. (17 How.) 284, 285-92, 294-99 (1854) (argument of counsel); id. at 305-12 (McLean, J., dissenting); Marbury v. Madison, 5 U.S. (1 Cranch) 137, 162 (1803) (dicturn). 


\section{Enter the Supreme Court}

To make a long story at least a bit shorter, ${ }^{93}$ present doctrine concerning the applicability of the Constitution to territories grew out of a series of cases precipitated by America's acquisition of far-flung, noncontiguous island territories during and shortly after the Spanish-American War of 1898. ${ }^{94}$ These so-called "Insular Tariff Cases," 1901, concerned duties levied on goods imported from Puerto Rico into the continental United States. ${ }^{96}$ In Downes v. Bidwell, ${ }^{97}$ the nost significant of the Insular Tariff Cases, the Court held that a tariff imposed by Congress on goods imported from Puerto Rico into the continental United States ${ }^{98}$ did not violate the constitutional requirement that "all Duties, Inposts and Excises shall be uniform throughout the United States." A9 Although the Justices in the majority in Downes could not agree on a rationale for the decision, ${ }^{100}$ the case produced a square

93. For longer versions of the story, see Coudert, supra note 14; Laughlin, The Burger Court and the United States Territories, 36 U. FLA. L. REV. 755, $762-74$ (1984) [hereinafter Laughlin, The Burger Court]; Laughlin, American Samoa, supra note 14, at 343-55.

94. See, e.g., Laughlin, The Burger Court, supra note 93, at 762-63 (discussing acquisition of the Hawaiian Islands, Puerto Rico, Guam, the Philippines, and part of the Samoan archipelago).

95. See De Lima v. Bidwell, 182 U.S. 1, 2 (1901). The Court itself employed the term.

96. De Lima was the first-and least important - of these cases. In De Lima, the Court held that, as a matter of statutory construction, Puerto Rico ceased to be a "foreign country" within the meaning of the generally apphicable tariff law, Dingley Act, ch. 11, 30 Stat. 151, 151 (1897), upon its cession to the Umited States by Spam. De Lima, 182 U.S. at 200 . The Court applied the same reasoning in the other Insular Tariff Cases. See Goetze v. Umited States, 182 U.S. 221 (1901) (Hawaiian Islands); Fourteen Diamond Rings v. Umited States, 183 U.S. 176 (1901) (Philippimes); $c f$. Dooley v. Umited States, 182 U.S. 222 (1901) (presidentially imposed war tariff on goods imported from the continental United States into Puerto Rico ended upon ratification of the treaty of peace); Armstrong v. United States, 182 U.S. 243 (1901) (same).

97. 182 U.S. 244 (1901).

98. See Foraker Act, ch. 191, § 3, 31 Stat. 77, 77 (1900) (goods brought from Puerto Rico into the continental Umited States and vice versa are dutiable at fifteen percent of the generally applicable tariff rates).

99. U.S. ConsT. art. I, $\S 8$, cl. 1. This statement of the holding in Downes requires some explanation. The Constitution flatly forbids the imposition of tariffs on goods brought froin one state to another. See U.S. CoNST. art. I, § 9, cl. 6 ("nor shall Vessels bound to, or fron, one State, be obliged to enter, clear, or pay Duties in another"). It also requires, as previously noted, that all tariffs "shall be uniform throughout the United States." Id. § 8, cl. 1. Thus, if Puerto Rico is part of the Umited States for purposes of this uniformity provision, then goods travelling between Puerto Rico and any of the states inust be treated exactly like goods moving from state to state, which means that they cannot be subject to duty. Hence, the alleged uniformity problem in Downes was not that the Foraker Act provided for duties at fifteen percent rather than one hundred percent of the regnlar tariff rate, but that it imposed any duties at all on goods imported from Puerto Rico into the rest of the United States.

100. Compare Downes, 182 U.S. at 279, 282 (dictum) (opimion of Brown, J.) ("[T]he Constitution is applicable to territories . . . only when and so far as Congress shall so direct," at least with respect to "what may be termed artificial or remedial rights, which are peculiar to our own system of jurisprudence.") and id. at 342 (White, Shiras, \& McKe1ma, JJ., concurring) (tlie uniformity clause did not bind Congress in legislating for Puerto Rico "because the island liad not been incorporated into the United States, but was inerely appurtenant thereto as a possession") with 
holding that at least one provision of the Constitution, which is plainly phrased as a limitation on congressional power, does not apply to congressional legislation respecting the territories in the same way that it must apply to the same or similar legislation respecting the states. ${ }^{101}$

Although the Insular Tariff Cases raised only the seemingly dry question of the territories' tariff status, it is clear from a full reading of the several opinions, the arguments of counsel, ${ }^{102}$ and the historical context ${ }^{103}$ that these cases were generally understood to be a broad referendum on the freedom of Congress to deal with the island territories in ways at least facially prohibited by the Constitution. More specifically, the larger question lurking in the background was whether all the provisions in the Bill of Rights concerning civil and criminal procedure had to be fully extended to territories populated, in the pointed and revealing words of Justice Henry Brown, "by alien races, differing from us in rehgion, customs, laws, methods of taxation and modes of thought." 104 In 1903, two years after Downes, the Court exphicitly addressed that question, refusmg to apply certain of the Constitution's criminal procedure

id. at 345 (Gray, J., concurring) (agreeing "in substance" with the concurring opinion of Justice White).

101. See also Dooley v. United States, 183 U.S. 151 (1901) (upholding a duty on goods brought into Puerto Rico froun the continental Uinted States, notwithstanding the Constitution's prohibition on taxes or duties "on Articles exported from any State") (quoting U.S. CoNST. art. I, § 9, cl. 5).

102. See generally THE INSUlar Cases, CoMprising THE Records, Briefs, AND Arguments of Counsel in the INSUlar Cases of THE OCtober Term, 1900, IN THE

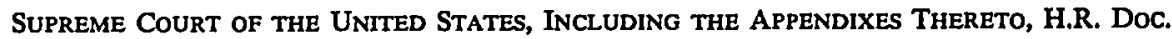
No. 509, 56th Cong., 2d Sess. (A. Howe ed. 1901) [hereinafter THE Insular CASES] (reprinting the lower court record, briefs and arguments of counsel).

103. For a brief summary of the historical context, see Coudert, supra note 14, at 823 ("It is difficult to realize how fervent a controversy raged [at the turn of the century] over the question of whether the Constitution follows the flag. ... It led ... to a bitterness which alnost threatened to reseinble the controversies over the Fugitive Slave Law and the Missouri Compronise.").

104. Downes, 182 U.S. at 287. The sentiments voiced by Justice Brown found expression in other Supreme Court opinions over the next twenty years:

The jary system needs citizens trained to the exercise of the responsibilities of jurors. . . . Congress has thought that a people like the Filipinos or the Puerto Ricans, trained to a coinplete judicial system which knows no juries, hiving in conipact and ancient communities, with definitely formed customs and political conceptions, should be permitted themselves to determine how far they wish to adopt this nistitution of AngloSaxon origin, and when.

Balzac v. Puerto Rico, 258 U.S. 298, 310 (1922);

If the right to trial by jury were a fundamental right which goes wherever the jurisdiction of the Umited States extends ... it would follow that, no matter what the needs or capacities of the people, trial by jury, and in no other way, must be forthwith established, although the resuit inay be to work injustice and provoke disturbance rather than to aid the orderly administration of justice. If the United States, impelled by its duty or advantage, shall acquire territory peopled by savages, and of which it may dispose or not hold for uitimate admission to Statehood, if this doctrine is sound, it must establish there the trial by jury. To state such a proposition deinonstrates the inipossibility of carrying it into practice.

Dorr v. Umited States, 195 U.S. 138, 148 (1904). 
provisions to trials in the island territories, ${ }^{105}$ though again the Court reached no clear agreement on a rationale.

By 1922, however, after two decades of litigation, ${ }^{106}$ the Court could unanimously treat as settled law ${ }^{107}$ a theory-first advanced by Justice Edward White in a concurring opinion in Downes, ${ }^{108}$ and first seemingly adopted by a majority of the Court in $1904^{109}$ - that has come to be known as the "doctrine of territorial incorporation."110 The doctrine turns upon a none-too-clear distinction between territories that have and territories that have not been "incorporated into the Union," 111 a decidedly inurky phrase originated by Justice White ${ }^{12}$ that probably has something to do with a territory's perceived suitability as a candidate for statehood. ${ }^{113}$ If a territory is incorporated, then all provisions of the

105. See Hawaii v. Mankichi, 190 U.S. 197 (1903) (5-4 decision, with two Justices concurring specially) (no constitutional or statutory right to indictment by grand jury or conviction by a unanimous petit jury in the Hawaiian Islands).

106. See Ocampo v. U1nited States, 234 U.S. 91 (1914) (9-0 decision) (no constitutional or statutory right to indictment by grand jury in the Philippines); Dowdell v. U1rited States, 221 U.S. 325 (1911) (8-1 decision) (no statutory right-and by implication no constitutional right-to indictunent by grand jury in the Philippines); Dorr v. United States, 195 U.S. 138 (1904) (8-1 decision, with three concurring Justices specifically repudiating much of the inajority's reasoning) (no constitutional or statutory right to jury trial in the Philippines); cf. Grafton v. United States, 206 U.S. 333 (1907) (while the same offense may be tried in federal and state courts without raising double jeopardy problems, that is not true when the same offense is sought to be tried in federal and territorial courts, sinee the latter derive their powers from the United States rather than from an independent source of sovereignty); Gonzalez v. Williams, 192 U.S. 1 (1904) (citizens of Puerto Rico are not aliens within the meaning of the immigration laws); Kepner v. United States, 195 U.S. 100 (1904) (prohibition on double jeopardy applies to the Philippines by statute); Mendezona v. Urnited States, 195 U.S. 158 (1904) (following holding in Kepner). Compare Rasmussen v. U1nited States, 197 U.S. 516 (1905) (constitutional right to jury trial applies in Alaska because the territory was incorporated into the United States by treaty nianifesting the intention to grant citizenship to the inhabitants) with id. at 528 (Harlan, J., concurring) (constitutional right to jury trial apphies in Alaska because it applies in all territories) and id. at 531 (Brown, J., concurring) (constitutional right to jury trial apphies in Alaska because Congress so said).

107. See Balzac v. Puerto Rico, 258 U.S. 298 (1922) (9-0 decision) (no constitutional or statutory right to jury trial in Puerto Rico for misdemeanors).

108. See Downes, 182 U.S. at 287 (White, J., concurring).

109. See Dorr, 195 U.S. at 148-49 (five justices held that only fundamental provisions of the Constitution extend to territories not nade part of the United States).

110. See generally Coudert, supra note 14 , at 823 .

111. Balzac, 258 U.S. at 305.

112. See Downes, 182 U.S. at 299 (White, J., concurring):

The sole and only issue ... is, whether the ... [special tariff on goods imported from

Puerto Rico] was levied in such form as to cause it to be repugnant to the Constitution.

This is to be resolved by answering the inquiry, Had Puerto Rico, at the time of the passage

of the act in question, been incorporated into and become an integral part of the United States?

113. See United States v. Verdugo-Urquidez, $110 \mathrm{~S}$. Ct. 1056, 1062 (1990) (describing unincorporated territories as possessions "not clearly destimed for statehood"); Granville-Simth v. Granville-Smith, 349 U.S. 1, 5 (1955) (referring to unincorporated territories as "possessions of the United States not thought of as future States"); see also Coudert, supra note 14, at 834 ("I surmise, although it is not wholly clear, that Mr. Justice White thought incorporation as a Territory inplied a promise of ultiniate stateliood."). As a description of the original intendment of the incorporation 
Constitution are said to be "apphicable"114 to that territory of their own force, or ex proprio vigore. If a territory is unincorporated, then only those provisions of the Constitution that are "fundamental"115 are apphcable in that territory ex proprio vigore; the rest are applicable only if and to the extent that Congress has so directed. ${ }^{116}$ The decisions do not explaim how to distinguish fundamental from non-fundamental constitutional provisions, but the holdings imdicate that the former category does not mclude the right to jury trial im criminal cases ${ }^{117}$ or the right to indictment by grand jury. 118

\section{Much Ado About Nothing?}

While the incorporation doctrime has seemed on shaky ground in the Court on several recent occasions, ${ }^{119}$ it is still at least nominally apphied as the governing test to determine which constitutional provisions apply in particular territorial settimgs. ${ }^{120}$ The doctrine, however, disinte-

doctrine, this at least has the virtue of explaining why, at the turn of the century, Alaska was regarded as incorporated, see Rasmussen v. Umited States, 197 U.S. 516, 525 (1905), while the distant islands teeming with "alien races," Downes, 182 U.S. at 287, were not. The vices of the incorporation doctrine in other respects are too numerous to mention. I take comfort in the evident inability of anyone else to define incorporation more precisely. See, e.g., Balzac, 258 U.S. at 305-13; Laughlin, The Burger Court, supra note 93, at 766-74; see also Downes, 182 U.S. at 391 (Harlan, J., dissenting) ("I am constrained to say that this idea of 'incorporation' has some occult meaning which my mind does not apprehend. It is enveloped in some mystery which $I$ am unable to unravel.").

114. Downes, 182 U.S. at 292 (White, J., concurring).

115. Balzac, 258 U.S. at 312.

116. The Court's most lucid description of the incorporation doctrine is found in Balzac. The Court explained why "the legislative recognition that federal constitutional questions may arise in hitigation in Puerto Rico," Balzac, 258 U.S. at 312, did not establish that Puerto Rico was an incorporated territory:

The Constitution of the Umited States is in force in Puerto Rico as it is wherever and whenever the sovereign power of that government is exerted. This has not only been admitted but einphasized by this court in all its authoritative expressions upon the issues arising in the Insular Tariff Cases, especially in the Downes y. Bidwell and the Dorr Cases. The Constitution, however, contains grants of power and limitatious which in the nature of things are not always and everywhere applicable, and the real issue in the Insular Tariff Cases was not whether the Constitution extended to the Philippines or Puerto Rico when we went there, but which of its provisious were applicable by way of linitation upon the exercise of executive and legislative power in dealing with new conditions and requirements. The guarantees of certain fundamental personal rights declared in the Constitution, as for instance that no person could be deprived of life, hberty or property without due process of law, had froin the beginning full apphication in the Philippines and Puerto Rico, and, as this guaranty is one of the most fruitful in causing litigation in our own country, provision was naturally made for similar controversy in Puerto Rieo.

Id. at $312-13$.

117. See supra note 106 (Dorr case); supra note 105 (Mankichi case).

118. See supra note 106 (Ocampo case); supra note 105 (Mankichi case).

119. See Reid v. Covert, 354 U.S. 1, 14 (1957) (plurality opinion) ("[I]t is our judgment that neither the [Insular Tariff] cases nor their reasoming should be givell any further expansion."); Torres v. Puerto Rico, 442 U.S. 465, 475-76 (1979) (Breunan, Stewart, Marshall \& Blackmun, JJ., concurring) (agreeing with, and citing, the plurality sentiment expressed in Reid v. Covert).

120. See Umited States v. Verdugo-Urquidez, 110 S. Ct. 1056, 1062 (1990); Torres, 442 U.S. at 
grates-not that it was ever especially coherent-as soon as one tries applying it to a provision like the appointınents clause. Since Guam is an unincorporated territory ${ }^{121}$ to which Congress has not specifically extended the appointments clause by statute, ${ }^{122}$ if the appointments clause apphes to Guamanian territorial officials, it must be by virtue of the fact that the clause is "fundamental." But it makes no sense even to consider the "fundamentality" of such a provision in the abstract, divorced from the Constitution's overall structure. One can ask whether a particular system of separation of powers is "fundamental," but it is profoundly wrong to ask the question of individual clauses. It seeins likely that the incorporation doctrine was devised solely with the Constitution's direct guarantees of personal rights in mind. ${ }^{123}$

Moreover, readers well versed in the law of federal jurisdiction will have noticed that the full and immediate apphication of the Constitution in incorporated territories is at odds with the long-established view, typically traced back to American Insurance Co. v. 356 Bales of Cotton, ${ }^{124}$

468-71. Professor Laughlin approvingly describes the modern understanding of the incorporation doctrine, exemplified by King v. Morton, 520 F.2d 1140 (D.C. Cir. 1975), as "the rule that there is a presumption of constitutional applicability in the territories which can be rebutted only by a clear and convincing showing that the application of a specific constitutional provision in a particular context would be inpractical or anoinalous." Laughlin, The Burger Court, supra note 93, at 780.

121. See 48 U.S.C. $\$ 1421$ a (1988) (identifying Guam as "an unincorporated territory of the United States").

122. See id. $\S 1421 b$ (specifying a lengthy list of constitutional provisions-and slightly altered versions of provisions-apphicable to Guam, but not including the appointınents clause).

123. This is somewhat iromic, as the provision for uniform tariffs specifically at issue in Downes is a structural rather than a directly personal protection. Of course, since the object of structural constraints is the (indirect) protection of personal liberty, the personal/structural dichotomy cannot be pressed too far.

124. 26 U.S. (1 Pet.) 511 (1828). From the date of its issuance, the decision has generally been cited as American Insurance Co. y. Canter. See, e.g., Northern Pipeline Constr. Co. v. Marathon Pipe Line Co., 458 U.S. 50, 64 (1982) (plurality opinion); id. at 106 (White, J., dissenting); Clinton v. Englebrecht, 80 U.S. (13 Wall.) 434, 447 (1872); Benner v. Porter, 50 U.S. (9 How.) 235, 240 (1850); M. Redish, Federal JuRisdiction: Tensions in the Allocation of Judicial Power 36 (1980); C. WRIGHT, THE LAW OF FEDERAL COURTS 40 (4th ed. 1983); Currie, The Constitution in the Supreme Court: The Powers of the Federal Courts, 1801-1835, 49 U. CHI. L. REV. 646, 716 (1982); Fallon, of Legislative Courts, Administrative Agencies, and Article III, 101 HARV. L. REV. 916, 916 n.2 (1988). But see Ngiraingas v. Sanchez, 110 S. Ct. 1737, 1749 (1990) (Brennan, J., dissenting) (citing the case as American Ins. Co. v. 356 Bales of Cotton); United States v. Dalcour, 203 U.S. 408, 427 (1906) (same). Compare Umited States v. Coe, 155 U.S. 76, 80 (1894) (argument of counsel citing the case as American Insurance Co. v. 356 Bales of Cotton) with id. at 85 (opinion of the Court citing the case as American Insurance Co. v. Canter). With all due respect, I join the dissenters. Although process was issued against Canter in personam, see American Insurance Co., 26 U.S. (1 Pet.) at 513, the case was primarily an action in rem for possession of specific bales of cotton (or their proceeds upon sale). See id. ; Canter v. American Ins. Co., 28 U.S. (3 Pet.) 307, 315 (1830); see also infra text accompanying notes 209-27. The captions in the record, see Record at 1 , American Insurance Co., 26 U.S. (1 Pet.) 511 (No. 1415) (available on microfilm, U.S. Nat'l Archives Microfilm Publications, Microcopy No. 214, Roll 74 at frame no. 667), and in the United States Reports, see American Insurance Co., 26 U.S. (1 Pet.) at 511, reflect this view, to which I will stubbornly cling with my expiring breath. 
that territorial courts need not satisfy the structural requirements of article III, even in territories that post-1901 jurisprudence would regard as incorporated. ${ }^{125}$ Yet the first case in which a majority of the Court purportedly accepted the territorial incorporation doctrine treated American Insurance Co. as a leading authority. ${ }^{126}$

The reason for this evident lack of concern about the problem of separation of powers in territorial governance is not difficult to discern: at the time the Insular Tariff Cases were decided, considerable authority suggested that the Constitution imposed few, if any, restraints on the composition of territorial governments. In his concurring opmion in Downes v. Bidwell, ${ }^{127}$ which spawned the imcorporation doctrine, Justice White set forth a number of principles which he took to be either uncontroversial or clearly established by settled authority. One sueh principle is that Congress has essentially a free hand with respect to the structure of the territorial governments it creates:

The Constitution has undoubtedly conferred on Congress the right to create such muricipal organizations as it may deem best for all the territories of the United States whether they have been incorporated or not, to give to the inhabitants as respects the local governments such degree of representation as may be conducive to the public well-being, to deprive such territory of representative government if it is considered just to do so, and to change such local governments at discretion.

The plenitude of the power of Congress as just stated is conceded by both sides to this controversy. It has been manifest from the earliest days and so many examples are afforded of it that to refer to them seems superfluous. ${ }^{128}$

Justice White's view was, as he suggested, supported by powerful authorities, though not the ones he invoked. ${ }^{129}$ Joseph Story, for exam-

125. Given that it has been assumed since American Insurance $C o$. that one does not have a right in the territories-whether incorporated or unincorporated-to have trials conducted by judges enjoying the tenure and salary guarantees of article III, see infra note 241 and acconpanying text, one could argue that it follows a fortiori that the "right" to be governed by a presidential appointee rather than an elected official cannot possibly be fundamental. On the other hand, one could argue that separation of powers is a critical bulwark of liberty that is more important in its own way than specific guarantees of particular rights. See Morrison v. Olson, 487 U.S. 654, 708-15, 727, 732-34 (1988) (Scalia, J., dissenting). Accordingly, exceptions to the application of the Constitution's separation of powers provisions to the territories should be strictly construed, if not overruled outright. In particular, this argument would continue, the faet that territorial courts are permitted outside article III should be treated as an anomaly, jnstified (if at all) by the belief that life tenure is inappropriate for officials in territories in which the United States' presence may be transitory. See O'Donoghue v. United States, 289 U.S. 516, 536-37 (1933).

126. See Dorr v. Uurited States, 195 U.S. 138, 141-42 (1904).

127. 182 U.S. 244,287 (1901) (White, J., concurring).

128. Id. at $289-90$ (footnote omitted).

129. Justice White's opinion cited only United States v. Kagaina, 118 U.S. 375, 378 (1886), and Shively v. Bowlby, 152 U.S. 1, 48 (1894). Downes, 182 U.S. at 290 n.1 (White, J., concurring). Neither case is strictly on point. The latter stated only "that Congress has the power to make grants 
ple, had thought it obvious that "the form of government established in the territories depends exclusively upon the discretion of congress. Having a right to erect a territorial government, they inay confer on it such powers, legislative, judicial, and executive, as they may deem best." ${ }^{130} \mathrm{~A}$ unanimous Court had expressed the same view in dictum in $1850 .{ }^{131}$ And although the majority and dissentimg Justices in the Dred Scott case ${ }^{132}$ could agree on virtually nothing else, they had been umited in behieving that " $[\mathrm{t}] \mathrm{he}$ form of government to be estabhshed [m acquired territories] necessarily rested in the discretion of Congress."133

These authorities suggest a simple answer to the problem posed by the facts of Sakamoto: If Congress wants to create territorial governinents with elected governors, it may do so, since it is a question of governmental structure committed entirely to its discretion. On this reasoning, the fact that all the territories were run by presidentially appointed officials for 150 years was due to legislative choice, not constitutional compulsion. If the First Congress thought otherwise, it was simply imistaken.

The formalist analysis based on strict separation of powers thus runs counter not only to the rather vague inodern case law on the Constitution's applicability to territories, but also to a clearer, inore venerable tradition specifically pertaining to territorial governmental structure. It is therefore worthwhile to look closely and critically at the constitutional history of the principal organs of American territorial governance givmg rise to this tradition. The history can perhaps help test the limits of formalisin, and formalisin - to the extent that it is viewed as a legitimate, even if nonexclusive, constitutional value-can perhaps help define the appropriate limits of the history.

\section{III \\ CONSTItutional History aND TeRritorial Structure}

Almost no one would be surprised to discover that soine of our long-

of land below high water mark of navigable waters in any Territory of the United States." Shively, 152 U.S. at 48 (dictun1). The former held only that Congress has power to legislate concerning the relations among Indians on reservations, see Kagama, 118 U.S. at 384-85, though it did contain sone broad dicta (on pages not cited by Justice White) regarding Congress' power to create territorial governnients. See id. at 379-80.

130. J. Story, COMmentaries ON THE CONSTTtUTION OF THE UNTTED STATES $\S 667$ (Boston 1833).

131. See Benner v. Porter, 50 U.S. ( 9 How.) 235, 242 (1850) (territorial governunents are not subject to the Constitution's "coniplex distribution of the powers of governinent, as the organic law; but are the creations, exclusively, of the legislative departnent, and subject to its supervision and control").

132. Dred Scott v. Sandford, 60 U.S. (19 How.) 393 (1857).

133. Id. at 448-49 (opinion of the Court); cf. id. at 623 (Curtis, J., dissenting) (agreeing with majority). 
established, long-upheld institutions of territorial governance are inconsistent with a formalist understanding of the Constitution. What inay be surprising is the extent of that inconsistency. Froin a formalist perspective, serious constitutional probleins have pervaded nearly every institution of territorial government since the nation's founding. More pointedly, a persistent, if not consistent, theine of territorial administration has been to try to afford territories as much opporturity for selfgovernment as Congress deeins conditions will permit, either as a prelude to statehood or simply as a reflection of a general commitment to deinocratic political theory. While the notion that territories must be governed autocratically as colonies is unlikely to have much normative appeal in this day and age, semideniocratic institutions of self-governinent, such as the elected Guamamian governor, are among the features of our territorial structure that raise the most serious constitutional probleins for formalists. The rest of Part III explains why.

\section{A. Article III and Territorial Judges}

The territorial institution best known to legal scholars-and whose demise would likely cause formalists the least distress-is the territorial court. Territorial judges neither "hold their offices during good behaviour"134 nor "receive for their services, a coinpensation, which shall not be diminished during their continuance in office,"135 as article III of the Constitution requires for "judges, both of the supreme and inferior courts."136 For example, Congress has created a District Court of Guam with "the jurisdiction of a district court of the United States . . . and that of a bankruptcy court of the United States." 137 Unlike regular, hfe-tenured district judges, the District Judge of Guam is appointed for "the term of ten years ... unless sooner renioved by the President for cause."138 Although the judge's pay is pegged by statute to the salary of article III district court judges, ${ }^{139}$ the federal courts will not recognize any article III barrier to a diminution of his salary. ${ }^{140}$ The court systein in Guam is clearly far renioved from the article III nodel. ${ }^{141}$

134. U.S. CoNST. art. III, $\S 1$.

135. Id.

136. Id.

137. 48 U.S.C. $\S 1424$ (b) (1988); see also id. $\S 1612$ (a) (same provision for a district court of the Virgin Islands).

138. Id. § $1424 \mathrm{~b}(\mathrm{a})$; see also id. $\$ 1614$ (a) (same provision for district judges of the Virgin Islands).

139. See id. § 1424b(a); see also id. § 1614(a) (same in the Virgin Islands).

140. See McAllister v. United States, 141 U.S. 174, 180 (1891) (Alaska district court judge could be removed by President); United States v. Fisher, 109 U.S. 143, 145 (1883) (Congress could prescribe a lower salary for a territorial justice than was fixed in a prior statute).

141. The Samoan courts, which have general civil and criminal jurisdiction, see AM. SAMOA CODE ANN. $§ 3.0103$ (1981), are even further removed from the article III model. The chief justice 
The absence of article III guarantees makes these territorial judges vulnerable to both direct and indirect control by the political branclies through threatened or actual salary reductions, removals, or denials of reappointment. More to the poimt for formalists, smce the activities of these judges cannot plausibly be considered legislative or executive, they must be either untenured judicial officers, in violation of the plain terms of article III, or officers of no particular branch, in violation of the equally plain tripartite constitutional structure. The Constitution could not be clearer on tlns poimt: it vests "tlie judicial Power of the United States"-all of it, every last scrap-in courts staffed by judges who enjoy tenure during "good Behaviour" and assurances that their compensation "shall not be diminished during their Continuance in Office."142 One can argue about whether certain governmental functions are exercises of judicial power, executive power, or both, but once an activity is deemed judicial, the Constitution makes unmistakably clear tlie kinds of officers who inust perform it. The story of how the federal courts avoided this seemingly obvious conclusion is annong the most mysterious in American constitutional history.

\section{The Golden Age}

The odyssey of territorial tribunals in the federal courts dates back to Marbury v. Madison ${ }^{143}$ in 1803 . Marbury was a mandanus action to compel Secretary of State Jaines Madison to deliver to William Marbury his signed commission as a justice of the peace for the District of Columbia, an office created by Congress im $1801^{144}$ pursuant to its authority "[t]o exercise exclusive Legislation in all Cases whatsoever, over [the District of Colunbia]." 145 The statute creating Marbury's office gave the District of Columbia justices of the peace the sane judicial powers and duties as their counterparts in Maryland or Virginia, ${ }^{146}$ but prescribed that the appointees should only "continue in office five years." 147 Thus, despite their adjudicative functions, the District of

and an associate justice are appointed for indefinite terms by the Secretary of the Interior, AM. SAMOA REV. CONST. art. III, \& 3 (1967), who may remove them for cause, AM. SAMOA CODE ANN. $\$ 3.1001$ (a) (1981). As in Guam, the justices' salaries are not constitutionally guaranteed. See supra note 140 .

142. U.S. CONST. art. III, $\S 1$.

143. 5 U.S. (1 Cranch) 137 (1803).

144. See Act of Feb. 27, 1801, ch. 15, § 11, 2 Stat. 103, 107.

145. U.S. ConsT. art. $1, \S 8$, cl. 17.

146. See Act of Feb. 27, 1801, § 11, 2 Stat. at 107:

[S]uch justices ... shall, in all matters, civil and criminal . . . have all the powers vested in, and shall perform all the duties required of, justices of the peace, as individual magistrates, by the laws herein before continued in force in those parts of said district, for which they shall have been respectively appointed; and they shall have cognizance in personal demands to the value of twenty dollars, exclusive of costs ....

147. Id. 
Columbia justices of the peace were neither regarded nor constituted by Congress as life-tenured "judges of inferior courts" within the meaning of article III. ${ }^{148}$

In the course of opining that Marbury had a vested right to his office and commission, Chief Justice Marshall declared on no fewer than five occasions that Marbury was not removable at the will of the President once Madison had signed and sealed the commission, thus legally appointing him. ${ }^{149}$ This dictum on Marbury's tenure was consistent with two propositions of very different breadth. It might simply have reflected the idea that Congress could himt the President's removal power over at least some officers by giving them a fixed term of office, which is clearly what Marshall had in mind. ${ }^{150}$ But the President's inability to remove Marbury would also follow from the view that Marbury, as a judicial officer, was constitutionally entitled by article III to tenure during good behavior, regardless of the terms of the statute creating his office. ${ }^{151}$ The latter proposition, if it had been adopted in the nation's formative years as the Supreme Court's holding, could have had a profound influence on the course of American territorial governance.

Less than a year after the Court decided Marbury, a holding of precisely such magnitude emerged from a circuit court in United States v. More. ${ }^{152}$ Like Marbury, Benjamin More was appointed a justice of the peace for the District of Columbia. Unlike Marbury, he took office without incident, although the tranquility was short-lived. The 1801 statute creating More's office contained a clause entitling District of Columbia

148. U.S. CONST. art. III, $\S 1$; see supra note 72. This appears to have been the first time that territorial judges were given a term of years rather than tenure during good behavior. $C$. Act of May 7, 1800, ch. 41, 3,2 Stat. 58, 59 (Indiana) (providing for tenure during good behavior); Act of May 26, 1790, ch. 14, §1, 1 Stat. 123, 123 (Tennessee) (same); Act of Apr. 7, 1798, ch. 28, $\S 3,1$ Stat. 549, 550 (Mississippi) (same); An Ordinance for the Government of the Territory of the United States north-west of the river Ohio (1787), reprinted at 1 Stat. 51 n.(a) (same). Terms of years, however, quickly became commonplace. See Act of Mar. 2, 1819, ch. 49, § 7, 3 Stat. 493, 495 (Arkansas) (term of four years, and providing for removal by the President); Act of June 4, 1812, ch. 95, $§ 10,2$ Stat. 743, 746 (Missouri) (term of four years, and providing for removal); Act of Mar. 26, 1804 , ch. 38, § 5, 2 Stat. 283, 284 (Orleans and Louisiana) (territorial judges "shall hold their offices for the term of four years").

149. See Marbury v. Madison, 5 U.S. (1 Cranch) 137, 155, 157, 162, 167, 172. If Marbury had in fact held his office at the President's pleasure, then President Jefferson's instructions to Madison to refuse to deliver Marbury's commission could be seen as a tacit exercise of the removal power, leaving Marbury with no claim on the office, commission, or salary, and leaving Marshall with no opportunity to side with Marbury on the merits before reaching the decisive jurisdictional issue.

150. Chief Justice Taft interpreted Marshall's comments this way in Myers v. United States, 272 U.S. 52 (1926), when he sought to establish the President's unlimited removal power over executive officers. See id. at 139-44.

151. This reading of Marbury was later argued to the Court. See infra text accompanying notes 171-73.

152. See Umited States v. More, 7 U.S. (3 Cranch) 159, 160 n.* (1805) (circuit court opinions, 1803). 
justices of the peace to charge hitigants for the performance of judicial services. ${ }^{153}$ More was appointed to his office while this fees-for-services provision was in effect. ${ }^{154}$ In 1802 , however, Congress declared that so inuch of the 1801 statute "as provides for the coinpensation to be inade to certain justices of the peace thereby created ... shall be, and is hereby repealed." 155 Seven inonths after this repealing statute took effect, More was criminally indicted for demanding and receiving a fee of twelve and one-half cents for adjudicating a minor debt action. ${ }^{156}$ In a demurrer to the indictment, More contended that the statute purporting to repeal his authority to collect fees was an unconstitutional attempt to reduce the salary of a federal judge and was thus without legal effect. ${ }^{157}$

The Circuit Court of the District of Columbia, in a split decision, agreed with More and dismissed the indictment in an overtly formalist opimion. ${ }^{158}$ Writing for the majority, Judge Cranch rejected out of hand the government's suggestion that Congress, in legislatimg for the District of Columbia, is not subject to any constitutional limitations. ${ }^{159}$ For Judge Cranch, as for formalists generally, the correct interpretation of the provision in article I empowering Congress " to exercise exclusive legislation in all cases whatsoever, over [the District]" "160 is that Congress may legislate for the District "in all cases where they are not prohibited by other parts of the constitution."161 That being so, Judge Cranch proceeded directly to an article III analysis. ${ }^{162}$ It did not occur to Judge Cranch, as it would not occur to a formalist, to try to distinguish provisions like article III's guaranty of judicial independence froin provisions like article I's guaranty of freedom from bills of attainder or ex post facto laws. ${ }^{163}$ In his view, if Congress was bound by the Constitution, it was bound by the Constitution as a whole, not simply the parts of the Constitution whose application was the least inconvenient.

Judge Cranch had a similarly easy time deciding whether More was a judge of an inferior court within the meaning of article III:

It is difficult to conceive how a magistrate can lawfully sit im judgment, exercising judicial powers, and enforcing his judgments by process

153. See Act of Feb. 27, 1801, ch. 15, \& 11, 2 Stat. 103, 107.

154. More, 7 U.S. (3 Cranch) at 165-66 (argument of Jones, counsel for More).

155. Act of May 3, 1802, ch. 52, § 8, 2 Stat. 193, 195.

156. More, 7 U.S. (3 Cranch) at 159.

157. Id. at 165-66 (argument of Jones).

158. Id. at $159,160 \mathrm{n}{ }^{*}$ (circuit court opinions, 1803).

159. Id. at 160-62 n.* (circuit court opinion of Cranch, J.).

160. Id. (quoting U.S. CoNST. art. I, $\S 8, \mathrm{cl} .17$ ) (emphasis added by circuit court in More).

161. Id.

162. Id. at $161 \mathrm{n.*}$.

163. U.S. CONST. art. I, $\S 9$, cl. 3 (prohibition against ex post facto laws and bills of attainder); cf. More, 7 U.S. (3 Cranch) at 160 n.* (Cranch, J., asking rhetorically whether Congress is bound by various article I provisions with respect to the District of Columbia). 
of law, without holding a court. I consider such a court, thus exercising a part of the judicial power of the United States, as an inferior court, and the justice of the peace as the judge of that court. ${ }^{164}$

In a somewhat extravagant, if admirable, display of judicial restraint, Judge Cranch noted that it was unnecessary to decide whether More had a constitutional right to hold his office during good behavior. ${ }^{165}$ "[B]ut that his compensation shall not be diminished during his continuance in office, seems to follow as a necessary consequence from the provisions of the constitution." 166

Judge Kilty dissented at some length, in language starkly prescient of the territorial incorporation doctrine that would einerge almost a century later: "[T]he provisions of the constitution, which are applicable particularly to the relative situation of the United States and the several states, are not applicable to this district."167 Congress, he stated, is prohibited from passing bills of attainder or ex post facto laws in the District of Columbia, ${ }^{168}$ but laws concerning the judiciary "cannot be tested by a provision in the constitution, evidently apphicable to the judicial power of the whole United States."169

John T. Mason, United States Attorney for the District of Columbia, sought review by writ of error $\mathrm{n} 1$ the Supreine Court, where he and More's counsel, Samuel Jones, resuined the argument. Jones defended the judgment below by echoing Judge Cranch's formalistic reasoning: the Constitution guards the salaries of federal judges, and More's federal office was as judicial as they come. ${ }^{170}$ Jones also nivoked the discussion of judicial tenure ni Marbury v. Madison, where Chief Justice Marshall declared that District of Columbia justices of the peace did not

164. More, 7 U.S. (3 Cranch) at 161 n.*.

165. See id.

166. Id. The government suggested that the fees-for-services provision was not a provision for compensation "at stated Times," U.S. CONST. art. III, $\S 1$, and could thus be reduced without violating the terms of article III. See More, 7 U.S. (3 Cranch) at 161 n.*. Judge Cranch, however, held that the phrase "at stated times" could include something bike "when the service is rendered." Id. "And," he added, "we are rather to incline to this construction, than to suppose the command of the Constitution to have been disobeyed." Id. The "command" he had in mind was presumably the requirement that judges receive some "Compensation," U.S. CONST. art. III, $\S 1$, which would have been violated if More's fees were unlawful.

167. Id. at $164 \mathrm{n}^{*}$ (opinion of Kilty, C.J.).

168. Id.

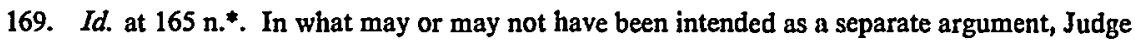
Kilty also suggested without elaboration that a comparison of the jurisdiction conferred by statute on District of Columbia justices of the peace with that conferred by the Constitution on federal courts, see U.S. CONST. art. III, § 2, cl. 1, demonstrated that any judicial power exercised by More was not "the judicial power of the United States" and hence was not the power provided for in article III. More, 7 U.S. ( 3 Cranch) at 163 n.* (quoting U.S. CoNST. art III, § 1) (emphasis in original).

170. See More, 7 U.S. (3 Cranch) at 167 (argument of Jones). 
serve at the pleasure of the President. ${ }^{171}$ That discussion was decisive, Jones argued, because Congress has no power to limit the removal of presidentially appoimted officers ${ }^{172}$ "unless in the case of a judge under the constitution."173 Thus, he reasoned, Marshall's statements in Marbury that the President could not remove District of Columbia justices of the peace at will must have rested on the understanding that article III applies fully to those justices. Given the full apphicability of article III, it would also be unconstitutional to diminish More's salary. ${ }^{174}$

In response, Mason advanced the arguments from Judge Kilty's dissenting opinion, and more besides. Judge Kilty thought that at least some provisions of the Constitution bind Congress in legislating for the District. ${ }^{175}$ Not so Mason, who averred that "Congress are under no controul in legislating for the district of Columbia. Their power, in this

171. Id. at 166; see supra text accompanying note 149.

172. See More, 7 U.S. (3 Cranch) at 166 . The courts had not squarely addressed the removal issue by that time. A definitive holding that the President has untrammeled removal power at least with respect to certain executive officers did not come until 1926, see Myers v. United States, 272 U.S. 52 (1926) (a law requiring Senate to consent to presidential attempts to remove postal officers held unconstitutional), and it lasted for less than a decade, see Humphrey's Ex'r v. United States, 295 U.S. 602, 631-32 (1935) (upholding certain restrictions on the President's removal power over Federal Trade Commissioners). For a summary of the incomprehensible state of current removal doctrine, see Morrison v. Olson, 487 U.S. 654, 685-93 (1988); id. at 723-27 (Scalia, J., dissenting); Liberman, supra note 18, at 335-42. The correct formalist view of the President's removal power is that "it depends." The only mode of removal discussed by the Constitution is impeachment, see U.S. CoNST. art. II, $\S 4$; any other mode mnst be established by inference. One could well infer, as did Hamilton, that whenever the Senate advises and consents to the appoimtinent of an officer, it mnst advise and consent to that officer's removal as well. See THE FEDERALIST No. 77, at 459 (A. Hamilton) (C. Rossiter ed. 1961). One could also beheve that Congress' power to create offices under the "necessary and proper" clause, U.S. CONST. art. I, $\S 8, \mathrm{cl} .18$, carries with it the power to set the terms of removal, or one conld believe that the removal power rests exclusively with the President. Whether any or none of these inferences is correct depends upon the answer to a question that has not, to my mind, been satisfactorily resolved. The executive power is vested by the Constitution "'m a President of the United States of America," id. art. II, $\$ 1$, cl. 1, who plainly must have the capability to execute the laws or to control and direct their execution. See Liberman, supra note 18 , at 315,353 . If the President cannot exercise his constitutional power directly by personally making any discretionary decisions committed by statute to subordinate officers (or at a minimum by issumg orders that invalidate contrary actions by subordinates), then we must infer an absolute presidential removal power in order to provide an indirect neehanism of executive control and direction. If the President does have the power to make all of the executive branch's discretionary decisions, an inference of a removal power becomes more difficult, and perhaps even untenable. See id. Does the President have such power? Like Ms. Liberman, I behieve that the President does, though how far that power goes, and how it interacts with Congress' power under the "necessary and proper" clause, are questions that do not yet have satisfactory answers, notwithstanding Ms. Liberman's heroic attempt to provide them. See id. at 352-58.

173. More, 7 U.S. (3 Cranch) at 166 (argument of Jones).

174. See $i d$. In response to the objection that More's office was not governed by article III under the 1801 statute becouse the office had a limited term of five years (instead of having a term for "good behavior"), Jones responded that "[i]t is not the tenure, but the essence and nature of the office which is to decide this question," and that "[i]f the limitation to five years makes a difference, it would be an evasion of the constitution." Id. at 167 .

175. See supra text accompanying note 168 . 
respect, is unlimited."176 Marbury, he argued, was not to the contrary, having determined only that Marbury had held office "during good behaviour for five years under the law; and not generally during good behaviour, under the constitution."177 Mason also denied that More's exercise of concededly judicial power necessarily brought him within article III. Mason argued that since the judicial power in the District of Columbia extended to cases not within the various heads of federal jurisdiction set forth in article III, it was not the judicial power of the United States. ${ }^{178}$ In other words, More's power niay well have been judicial, but it was territorial judicial power, springing not from article III but from article I's grant of power to Congress to legislate for the District.

Jones' rebuttal to this last argument speaks for itself:

The executive power exercised within the district of Columbia is the executive power of the Umited States. The legislative power exercised in the district is the legislative power of the United States. And what reason can be given why the judicial power exercised in the district should not be the judicial power of the United States? If it be not the judicial power of the United States, of what nation, state or political society is it the judicial power? All the officers in the district are officers of the United States.

By the 2d section of the third article of the constitution, the judicial power of the United States is to extend to all cases arising under the laws of the United States. All the laws in force in the district are laws of the United States, and no case can arise which is not to be decided by those laws. ${ }^{179}$

Although More was concerned with the District of Columbia, it is hard to imagine a case more clearly raising the key issues concerning the constitutional status of territorial tribunals generally. ${ }^{180}$ The Suprene Court never reached the merits in More, however, because Chief Justice Marshall sua sponte raised a decisive jurisdictional problein. ${ }^{181}$ Accord-

176. More, 7 U.S. (3 Cranch) at 168 (argument of Mason, counsel for the United States) (emphasis in original).

177. Id.

178. Id.

179. Id. at $168-69$ (argument of Jones).

180. Any arguments made concerning Congress' power under article I to legislate for the District could equally be made concerning Congress' power under article IV (or whatever other sources of power there may be) to legislate for the territories.

181. That problem is of considerable mterest in its own right. The same act of Congress that created More's office, Act of Feb. 27, 1801, ch. 15, § 11, 2 Stat. 103, 106, also created the District of Columbia Circuit Court that decided his case. See id. $\S 3,2$ Stat. at 105 . The act provided for Supreme Court review of "any final judginent, order or decree in said circuit court, wherein the inatter in dispute, exclusive of costs, shall exceed the value of one hundred dollars." Id. $\$ 8,2$ Stat. at 106. Marshall construed this language, and in particular the words "matter in dispute," to refer exclusively to civil cases. See More, 7 U.S. (3 Cranch) at 173-74. Marshall reasoned that an affirmative statutory description of the Supreme Court's appellate jurisdiction must be read to prohibit the exercise of powers other than those described, see id. at 173, and that Congress had 
ingly, the Court dismissed the writ of error for lack of jurisdiction; More got away scot-free; and a decision on the status of territorial tribunals had to await another day.

Less than a year after the Supreme Court's decision in United States v. More, the Court decided Wise v. Withers. ${ }^{182}$ Plaintiff-in-error Wise was, once again, a justice of the peace for the District of Columbia, who evidently did not report when called for militia duty. He was fined by a military court-martial, which sent the defendant Withers to collect the fine. Withers entered Wise's home and seized some of his goods, whereupon Wise brought an action for trespass vi et armis. ${ }^{183}$

The case turned upon whether Wise, as a justice of the peace, was exempt from service in the militia. The law governing the organization of the militia in the District of Columbia provided for the enrollment of all nonexempt, resident, able-bodied white males between the ages of eighteen and forty-five. ${ }^{184}$ Included among the categories of exempt persons were "the officers judicial and executive of the governinent of the United States." 185 The Court held that Wise was within this exemption. According to Chief Justice Marshall, the Court had already decided (presumably in Marbury v. Madison) that justices of the peace were "officers." 186 Withers had suggested that a distinction be drawn between officers of the Umited States, withm the meaning of the Constitution, and officers "of the government of the United States," within the meaning of the exemption statute. ${ }^{187}$ Marshall, however, would have none of it. In an eerie echo of Samuel Jones' formalistic argument in More, ${ }^{188}$ he held that Wise "must be an officer under the government of the United States. Deriving all his authority from the legislature and president of the Umited States, he certainly is not the officer of any other governinent." 189 That left ouly the question whether Wise's office was either "executive"

therefore implicitly used its power to define exceptions to the Supreme Court's appellate jurisdiction in order to preclude the Court from reviewing criminal cases decided by the Circuit Court of the District. See U.S. CoNST. art. III, § 2, cl. 2 (In all cases in which the Supreme Court does not have original jurisdiction, it "shall have appellate Jurisdiction, both as to Law and Fact, with such

Exceptions, and under such Regulations as the Congress shall make.").

182. 7 U.S. (3 Cranch) 331 (1806).

183. See id. at 331.

184. Act of Mar. 3, 1803, ch. 20, §6, 2 Stat. 215, 216.

185. Act of May 8, 1792, ch. 33, § 2, 1 Stat. 271, 272.

186. See Wise, 7 U.S. (3 Cranch) at 336. Marshall nevertheless indicated that he would also reach that conclusion as an original matter in view of the fact that Wise was appointed by the President subject to Senate confirmation. See id.

187. See id. (emphasis in original).

188. See supra text accompanying note 179. The echo is ecrie partly because of Marshall's subsequent abandonment of this argument in American Insurance Co. v. 356 Bales of Cottou, 26 U.S. (1 Pet.) 511 (1828), but inostly because apparently none other than Samuel Jones forcefully advanced the contrary position as counsel for Withers. See Wise, 7 U.S. (3 Cranch) at 333 (argument of Jones).

189. Wise, 7 U.S. (3 Cranch) at 336. 
or "judicial" within the meaning of the exemption statute. Marshall's affirmative answer was strikingly formalistic: "If a justice of the peace is an officer of the government of the United States, he must be either a judicial or an executive officer." 190 Since the case did not require the Court to assign Wise specifically to the executive or judicial branch, but merely to decide that he was necessarily within one of the two, Marshall added only that Wise's powers "seem partly judicial, and partly executive," 191 which was enough to exempt him from military service.

Though it did not address territorial tribunals, one other early decision deserves mention, as it suggests that territories are a constitutionally integrated part of the American polity, and thus are (or so one could argue) at least presumptively within the scope of the Constitution's structural provisions. In 1815, Congress had imposed a direct tax on the states for general revenue purposes, ${ }^{192}$ which it shortly thereafter extended to the District of Columbia. ${ }^{193}$ In Loughborough v. Blake, ${ }^{194}$ the Court upheld Congress' power to levy a direct tax on the District, invoking the authority in article I to "lay and collect Taxes, Duties, Iinposts and Excises." 195 Chief Justice Marshall reasoned that because this grant of power was general, it extended to "all places over which the government extends." ${ }^{196}$ He reinforced this conclusion by reference to the constitutional requireinent that duties, imposts, and excises be "uniform throughout the Uinted States." 197 Since this modification of the taxing power was plainly coextensive with the original grant of power, ${ }^{198}$ the taxing power inust extend throughout the United States. ${ }^{199}$ The question was thus whether "the Uinited States" includes the District of Columbia. Marshall thought the answer clear: "[The United States] is the name given to our great republic, which is composed of states and territories. The district of Columbia, or the territory west of the Missouri, is not less within the United States, than Maryland or Pennsylvamia ...."200 According to Marshall, Congress therefore had the power to extend a direct tax to the District of Columbia, but the

190. Id. This assumes, of course, that Congress was using the terms "executive" and "judicial" in their constitutional senses-an assumption that seems wholly justified.

191. Id.

192. See Act of Jan. 9, 1815, ch. 21, § 1, 3 Stat. 164, 164-65.

193. See Act of Feb. 27, 1815, ch. 60, § 1, 3 Stat. 216, 216.

194. 18 U.S. (5 Wheat.) 317 (1820).

195. U.S. CoNST. art. I, § 8, cl. 1. By locating the power to tax in this clause, rather than in Congress' legislative power over the District, Marshall avoided the potentially thorny question of whether the power over the District authorizes taxes for general revenues or only for local purposes. See Loughborough, 18 U.S. (5 Wheat.) at 318.

196. Loughborough, 18 U.S. (5 Wheat) at 318-19.

197. U.S. CoNST. art. I, § 8, cl. 1 (the "uniformity clause").

198. Loughborough, 18 U.S. (5 Wheat) at 319.

199. Id.

200. Id. 
effect of the "uniformity clause"201 was the requirement that any such tax be apportioned in accordance with the census, ${ }^{202}$ as was then required of direct taxes imposed in the states. ${ }^{203}$ One could then fairly ask: If a structural provision like the uniformity clause applies to the territories, why not other structural provisions as well? ${ }^{204}$

As the first quarter of the nineteenth century closed, formalists could survey the sccne with some satisfaction. United States v. More, the one square holding on the status of territorial tribunals (albeit issuing from a lower court), clearly held that territorial judges were fully federal judges under article III and were thus entitled to the guarantees of judicial independence found in the Constitution. The reasoning in both Marbury v. Madison and Wise v. Withers was consistent with this view. Loughborough v. Blake suggested, albeit ambiguously, that the territories were at least not wholly beyond the reach of the Constitution's structural provisions. And, as will be discussed later, ${ }^{205}$ Marshall's famous opinion in Osborn v. Bank of the United States, ${ }^{206}$ holding that all activities of a federally created corporation "arise under" federal law for purposes of article III, ${ }^{207}$ seemed in precise harmony with Samuel Jones' argument in More that all activity in the District of Columbia, including the exercise of judicial power, was necessarily federal. ${ }^{208}$ The conclusion that territorial judges exercised federal judicial power, and were thus entitled to the tenure and salary guarantces of article III, seeined inescapable.

\section{The Fall of the Formalist Empire}

In 1828, however, formalism received a blow from which it has never recovered. In American Insurance Co. v. 356 Bales of Cotton, ${ }^{209}$

201. See supra note 197 and accompanying text.

202. See Loughborough, 18 U.S. (5 Wheat) at 321-22, 325.

203. See U.S. ConsT. art. I, $\$ 9$, cl. 4.

204. The reasoming, if not the holding, of Loughborough is flatly inconsistent with the result in Downes v. Bidwell, 182 U.S. 244 (1901). Compare Loughborough, 18 U.S. (5 Wheat.) at 319 ("it is not less necessary, on the principles of our constitution, that uniformity in the imposition of imposts, duties, and excises, should be observed in the [territories], than in the [states]") with supra text accompanying notes $97-99$ (discussing holding in Downes that the uniformity clause did not invalidate a tariff imposed by Congress on goods imported from Puerto Rico into the continental United States).

205. See infra text accompanying notes 247-53.

206. 22 U.S. (9 Wheat.) 738 (1824).

207. See id. at 823; U.S. CoNsT. art. III, § 2, cl. 1 ("The judicial Power shall extend to all Cases, in Law and Equity, arising under ... the Laws of the United States . ...") (enuphasis added).

208. See supra text accompanying note 179. Osborn also sinoothed over the period's one rough spot for formalists. In Seré v. Pitot, 10 U.S. (6 Cranch) 332 (1810), Chief Justice Marshall suggested in dicta that territorial tribunals could hear cases which were outside the cognizance of the federal courts under article III. See id. at 337. Serés reasoning was substantially, if not totally, undermined by $O$ sborn's expansive interpretation of article III's "arising under" language. See infra note 245; text accompanying notes 247-59.

209. 26 U.S. (1 Pet.) 511 (1828). 
the Supreme Court, per Chief Justice Marshall, appeared to uphold the constitutional validity of territorial tribunals not conforming to article III. I say "appeared" because it is clear upon careful examination of the opinion that its discussion of the status of territorial courts was dictum, responding to an argument advanced by neither party. Moreover, the Court made no attempt to reconcile this dictum with its prior, and at least arguably inconsistent, case law: Marshall's murky opinion did not cite a single prior decision. Nevertheless, the opinion has been a cornerstone of all subsequent case law on territorial governance, and it both deserves and requires close scrutiny.

The case involved the distribution of authority among the territorial courts of Florida in 1825. Congress had vested "the judicial power of the territory of Florida . . . in three superior courts, and in such inferior courts, and justices of the peace as the legislative council of the territory may, from time to tinie, estabhsh."210 The superior courts were given broad original and appellate jurisdiction over territorial matters; ${ }^{211}$ and " $\mathrm{m}$ all cases arising under the laws and Constitution of the United States,"212 they were vested with "the same jurisdiction"213 that had been vested in the District Court of Kentucky by the Judiciary Act of 1789. ${ }^{214}$ The Judiciary Act, in turn, gave federal district courts "exclusive original cognizance of all civil causes of admiralty and maritime jurisdiction,"215 among other powers.

In 1823, the Florida legislative council responded to the frequent shipwrecks off the Florida coast by creating salvage courts to be adininistered by local officials inferior to the congressionally created superior court judges. Specifically, the statute provided that whenever wrecked property was brought into the territory, the salvors, owners, or other responsible persons were required to report the fact "to such justice of the Peace, or Notary Pubhic as may reside next adjacent to the place of

210. Act of May 26, 1824, ch. 163, 1,4 Stat. 45, 45. This statute amended the territory's organic act, which originally provided for only two superior courts. See Act of Mar. 3, 1823, ch. 28, $\S 7,3$ Stat. 750,752 . The organic act also created the territorial legislative council referred to in the text, which consisted of the governor plus thirteen presidentially appointed "fit and discreet persons of the territory," id. $\S 5,3$ Stat. at 751 , and which had power "over all rightful subjects of legislation." Id.

211. See Act of May 26, 1824, ch. 163, $\S 1,4$ Stat. 45, 45 (description of jurisdiction over territorial matters).

212. Id. $\S 2,4$ Stat. at 45 .

213. Id.

214. Judiciary Act of 1789 , ch. $20, \S 9,1$ Stat. 73.

215. Id. $\S 9,1$ Stat. at 77 . The Kentucky and Maine district courts had, in addition to the jurisdiction conferred generally on federal district courts, all the original jurisdiction of a circuit court. See id. $\S 10,1$ Stat. at 77-78. That additional jurisdiction was not relevant to any issue in American Insurance Co. 
arrival."216 The justice or notary ${ }^{217}$ would then summon a five-person jury, which would determine the disposition of the salvaged property. ${ }^{218}$ All judicial officers of the territory were limited by the Florida Organic Act to four-year terms of office. ${ }^{219}$

Trouble began on February 7, 1825, when the good ship Point $d$ Petre foundered on a reef off the coast of Florida while carrying a load of cotton, much of which was insured by the American Insurance Company and the Ocean Insurance Company. ${ }^{220}$ A portion of the cargo was saved by rescue ships and brought to Key West, where a notary and five jurors held court in accordance with Florida's salvage statute. The jurors awarded seventy-six percent of the value of the rescued cotton-an unusually large aniount-to the salvors. The presiding notary then conducted (and served as auctioneer at) a judicial sale, at which David Canter purchased 356 bales of the salvaged cotton. ${ }^{221}$ Canter took the cotton, or at least 300 bales of it, to Charleston, South Carolina, ${ }^{222}$ where he sold it to a broker who in turn resold it at auction. ${ }^{223}$ The imsurance coinpanies, which had acquired by abandonment the original shipper's interest in the cotton, filed a hibel (as complaints im admiralty were then called) in the District Court of South Carolina, claiming that the judicial sale in Key West was invalid and had not transferred ownership to Canter. ${ }^{224}$ The district judge agreed with the insurance companies that the Key West tribunal was incompetent to adjudicate salvage cases, on the ground that admiralty jurisdiction-which he took to include sal-

216. Record at 7, American Ins. Co., 26 U.S. (1 Pet.) 511 (No. 1415) [hereinafter Record] (available on microfilm, U.S. Nat'l Archives Microfilm Publications, Microcopy No. 214, Roll 74 at frame no. 667; two frames per page) (quoting Florida Territorial Legislative Council Act of July 4, 1823, § 1, repealed by Florida Territorial Legislative Council Act of Nov. 23, 1828, reprinted in Public Acts of the Legislative Council of the TerRitory of Florida 259 (J. Duval ed. 1839)). The record in this case is laandwritten, so iny reproduction of its punctuation and capitalization may not be entirely accurate.

217. A number of differences existed between the duties of justices of the peace and notaries public in Florida in the 1820s, cf. Florida Territorial Legislative Council Act of Feb. 15, 1834 (establishing schedule of fces for justices of the peace, notaries public, and others), reprinted in Public ACts of the Legislative Council of THE TeRritory GF Florida 212-13 (J. Duval ed. 1839), but as far as the salvage statute was conccrned, their duties were identical. $C f$. Record, supra note 216, at 13, 17-18 (indicating that notaries were generally regarded as judges of some sort).

218. See Record, supra note 216, at 7 (quoting Florida Territorial Legislative Council Act of July 4, 1823, §§ 2-4).

219. Act of Mar. 3,1823 , ch. $28, \S 10,3$ Stat. 750,753 . The full text of the statute makes clear that this limitation applied to territorially created as well as congressionally created local judges.

220. The two companies taken together had insured 684 of the 891 bales of cotton carried on the vessel, at a total value of $\$ 47,244.00$. See American Insurance Co., 26 U.S. (1 Pet.) at 514; Record, supra note 216 , at $1,15$.

221. See American Insurance Co., 26 U.S. (1 Pet) at 514, 541.

222. The record states only that between 300 and 356 bales of cotton showed up in Charleston under the control of Canter. See Record, supra note 216, at 2.

223. American Insurance Co., 26 U.S. (1 Pet.) at 513; Record, supra note 216, at 2.

224. See American Insurance Co., 26 U.S. (1 Pet) at 541. 
vage - could not be exercised by state or territorial courts. ${ }^{225}$ On crossappeals, ${ }^{226}$ Justice Johnson, sitting on circuit, reversed the judgment in favor of the insurance companies, holding the Key West sale valid and awarding all the cotton to Canter. 227

The insurance companies appealed to the Supreme Court, advancing two significant arguments. ${ }^{228}$ Neither argument questioned the general constitutional validity of territorial tribunals, nor even the ability of territorial tribunals to adjudicate salvage cases. Rather, the insurance coinpanies maintained in both arguments simply that the case had been brought in the wrong territorial court. The first argument was purely statutory. As noted eartier, the Judiciary Act of 1789 had given federal district courts "exclusive origimal cognizance of all civil causes of adiniralty and maritime jurisdiction," 229 and the territorial organic act gave the congressionally created Florida superior courts "the sanie jurisdiction ... in all cases arismg under the laws and Constitution of the United States" as was vested in the federal District Court of Kentucky. ${ }^{230}$ The insurance companies argued that if the jurisdiction of the two courts was "the sanie," then the admiralty jurisdiction of the superior courts must be "exclusive," and the territorial legislature was not free to confer such jurisdiction on locally created courts. ${ }^{231}$ The Supreme Court correctly rejected this argument for reasons that are of hittle concern here. ${ }^{232}$

225. See Record, supra note 216 , at 32 . The judge also doubted whether Congress intended to permit territorial courts to exercise admiralty jurisdiction. See id. at 34.

226. The insurance companies appealed because the district court awarded thein only 39 of the 356 bales they sought, citing as its reason the companies' inability to prove ownership of most of the cotton due to the obhteration of its identifying marks. See American Insurance Co., 26 U.S. (1 Pet.) at 513-14; Record, supra note 216, at 2.

227. See American Insurance Co., 26 U.S. (1 Pet.) at 514, 515 n.* (circuit court opinion of Johnson, J.).

228. They advanced two insignificant arguments as well. First, they made an ill-defined challenge to the power of the Florida legislature to establish salvage courts. See id. at 515. Second, they argued that jurisdiction was appropriate only in the superior courts because of the provision of the organic act giving those courts original jurisdiction in all civil actions arising under territorial laws and involving more than $\$ 100$. See id; Act of May 26, 1824, ch. 162, § 1, 4 Stat. 45, 45. As Justice Johnson pointed out in his opinion on circuit, see American Insurance Co., 26 U.S. (1 Pet.) at 522 n.*, nothing in this provision (apart from the arguments discussed in the text) foreclosed concurrent original jurisdiction over such actions in inferior territorial courts.

229. Judiciary Act of 1789, ch. 20, $\$ 9,1$ Stat. 73, 77 (emphasis added).

230. Act of May 26, 1824, ch. 163, $\S 1,4$ Stat. 45, $45-46$.

231. See American Insurance Co., 26 U.S. (1 Pet.) at 528-29 (argument of Mr. Ogden, counsel for appellants).

232. The Court pointed out that the jurisdiction of the Florida superior courts tracked that of the Kentucky district court only in eases "arising under the laws and Constitution of the United States," id. at 545, which article III makes clear are jurisdictionally distinct from admiralty. See id. at 545-46. Hence, the provision giving the two courts "the same jurisdiction" in cases arising under federal law did not establish that in admiralty cases Congress had vested exclusive territorial jurisdiction in the superior courts. Counsel for the insurance companies, anticipating this obvious problem, argued that all cases imvolving territorial tribunals necessarily arise under federal law within the meaning of article III, citing Osborn v. Bank of the United States, 22 U.S. ( 9 Wheat.) 738 
Unfortunately for posterity's sake, the insurance companies also had a constitutional argument against the jurisdiction of the Key West salvage court. The Constitution, they said, extends the judicial power of the United States "to all Cases of admiralty and maritime jurisdiction."233 Moreover, the judicial power is vested "in a Supreme Court, and such inferior Courts as Congress n1ay fron1 time to time establish."234 Thus, they argued, admiralty jurisdiction could be exercised in Florida only by congressionally created courts-namely, the superior courts. To the extent that Congress souglit to autliorize the territorial legislature to create courts witlı admiralty jurisdiction, it was prevented from doing so by article III. ${ }^{235}$

Marshall's response to this argument must be read to be disbelieved: [Article III] declares, that "the Judges both of the Supreme and inferior Courts, shall hold their offices during good behaviour." The Judges of the Superior Courts of Florida hold their offices for four years. These Courts, then, are not constitutional Courts, in which the judicial power conferred by the Constitution on the general government, can be deposited. They are incapable of receiving it. They are legislative Courts, created in virtue of the general right of sovereignty which exists in the government, or in virtue of that clause which enables Congress to inake all needful rules and regulations, respecting the territory belonging to the United States. The jurisdiction with which they are invested, is not a part of that judicial power which is defined in the $3 \mathrm{~d}$ article of the Constitution, but is conferred by Congress, in the execution of those general powers which that body possesses over the territories of the Umited States. Although admiralty jurisdiction can be exercised in the states in those Courts, only, which are established in pursuance of the $3 \mathrm{~d}$ article of the Constitution; the same limitation does not extend to the territories. In legislating for them, Congress exercises the combined powers of the general, and of a state government. ${ }^{236}$

This discussion extends far beyond the issues raised by the parties. The insurance compamies had assumed throughout their argument that a

(1824). See American Insurance Co., 26 U.S. (1 Pet.) at 536 (argument of Mr. Whipple, counsel for claimants); see also infra text accompanying notes 247-53 (discussing $O_{s b o r n}$ ). The Court did not even mention, much less respond to, this argument, which the insurance coinpanies plainly viewed as the backbone of their statutory claim. Perhaps the Court felt (correctly) that Justice Johnson's opinion on circuit had dealt adequately with this argument. See infra note 259. In any event, the issue was resolved by Congress in 1826 in favor of exclusive superior court admiralty jurisdictionone year too late to do the insurance companies any good. See Act of May 15, 1826, ch. 46, § 1, 4 Stat. 164, 164 (the Florida superior courts "shall have original and exclusive cognisance of all civil causes of admiralty and maritime jurisdiction").

233. American Insurance Co., 26 U.S. (1 Pet.) at 528 (argument of Mr. Ogden) (emphasis in original); see also U.S. CoNST. art. III, § 2, cl. 1 .

234. American Insurance Co., 26 U.S. (1 Pet) at 528 (argument of Mr. Ogden) (emphasis added); see also U.S. CoNST. art. III, $\S 1$, cl. 1.

235. See American Insurance Co., 26 U.S. (1 Pet.) at 529 (argument of Mr Ogden).

236. Id. at 546 . 
salvage action could have been brought in the territorial superior courts; at no time did they claim that admiralty jurisdiction in the territories could be vested only in federal district courts imbued with tenure and salary guarantees. ${ }^{237}$ This was certainly an unwise concession for the insurance coinpanies to have made, for if territorial courts need not conform to all of article III, it is difficult to explain why they should have to conform to the portions invoked by the imsurers. As the parties had frained the case, however, the constitutional validity of the territorial superior courts was simply not at issue, and Marshall's discussion of the point was gratuitous.

It was also fatuous. ${ }^{238}$ Marshall offered no substantial support for his assertion that article III does not apply to the territories; the undenied fact that Congress possesses "the combined powers of the general, and of a state government" when legislating for the territories does not establish that it can exercise those powers without constitutional constraint. $^{239}$ Apart from that assertion, Marshall's argunient amounts to the claim that because the superior court judges were not afforded article III's tenure guaranty, we might as well let those courts violate article III's jurisdictional provisions for good measure. ${ }^{240}$

Notwithstanding its analytic defects, American Insurance Co. was taken without discussion by the Court nearly half a century later as a general validation of territorial tribunals operating outside the linits of article III, ${ }^{241}$ and the case ever since has wreaked havoc with much of

237. Perhaps I am rash to claim that the insurance companies "at no time" made such an argument, as the record of the case does not contain the parties' briefs. Nonetheless, if any such argument had even been alluded to, one would expect some mention of it in the record (which included both lower court opinions), the summary of the arguments of counsel in the United States Reports, or the Court's opinion. There is none, other than the district court's somewhat cryptic holding that ncither state nor territorial courts can exercise admiralty jurisdiction. See Record, supra note 216 , at 32 .

238. See M. RED1SH, supra note 124, at $36-39$ (criticizing American Insurance Co.); C. WRIGHT, supra note 124, at 41 (describing the doctrine that territorial courts are created outside of article III as "of doubtful soundness"); Currie, supra note 124, at 719 (calling the discussion in American Insurance Co. "poorly explained" and "difficult to reconcile with the purposes of article III').

239. See Currie, supra note 124 , at 719 .

240. See id. at 717 ("Marshall viewed the fact that the territorial judges did not hold their offices during 'good Behaviour' as a factor supporting the constitutionality of their jurisdiction: article III did not apply because the judges had ouly four-year terms.").

Moreover, if Marshall was going to address the constitutional status of the Florida superior courts, he should have given the parties an opportunity to bricf the issue. The insurance companies, after all, did not have to concede that the superior courts were constitutionally proper. They would have been delighted by a ruling that neither the Key West court nor any other Florida territorial court had jurisdiction to preside over the sale of their cotton. If alerted to Marshall's plan to address the point, they surely would have resuscitated Samuel Jones' and Judge Cranch's old arguments on the applicability of article III to territorial tribunals. See supra text accompanying notes 159-66, 179.

241. See Clinton v. Englebrecht, 80 U.S. (13 Wall.) 434, 447 (1872) (The status of territorial 
the law of federal jurisdiction. ${ }^{242}$ Its culmination-or, if you prefer, reductio ad absurdum-came in 1973 in Palmore v. United States, ${ }^{243}$ which held that District of Columbia courts that did not conform to article III could nonetheless adjudicate criminal cases. ${ }^{244}$ That is quite a distance to travel from the argument and lower court opinion in United States v. More. ${ }^{245}$

courts as other than constitutional courts of the United States "was decided long since in The American Insurance Company v. Canter, and in the later case of Benner v. Porter.") (footnotes oinitted). Benner dealt with the status of territorial tribunals after their home territory became a state, holding that statehood automatically abolishes all territorial institutions. See 50 U.S. (9 How.) $235,244-45$ (1850). Its discussion of the status of such tribunals during the period of territoriality was thus clearly dictum.

242. The idea that Congress, without complying with article III, can create institutions to exercise what is arguably, if not plainly, judicial power has returned from the territories to roost in the republic. See generally Commodity Futures Trading Comm'n v. Schor, 478 U.S. 833, 847-57 (1986) (validating CFTC reparations proceeding conducted by administrative law judge); $\mathbf{M}$. REDISH, supra note 124, at 36-51 (discussing wide range of adjudication by administrative bodies outside article III under modern administrative statutes); C. WRIGHT, supra note 124, at 39-49 (same); Fallon, supra note 124 (same); Redish, Legislative Courts, Administrative Agencies, and the Northern Pipeline Decision, 1983 DUKE L.J. 197 (same). American Insurance Co. may also have helped spawn the territorial incorporation doctrine. See supra text accompanying notes 107-18. As Professor Currie has sagely observed, "The first small step down the road to perdition may prove to be irreversible." Currie, supra note 124 , at 719 .

243. 411 U.S. 389 (1973).

244. Id. at 410. For a criticisin of Palmore, sec M. REDISH, supra note 124, at 47-49.

245. 7 U.S. (3 Cranch) 159 n.* (1805) (reprinting circuit court opinion). See supra text accompanying notes 152-66, 179. Professor Neuman has defended the operation of territorial courts outside the linits of article III by pointing to the anoinalous gap in federal court jurisdiction which would otherwise result. See Neuman, Whose Constitution?, 100 Yale L.J. (forthcoming 1991). When American Insurance Co. was decided in 1828, the Court had already held-correctly-in Corporation of New-Orleans v. Winter, 14 U.S. (1 Wheat.) 91 (1816), that citizens of territories were not citizens of any state for purposes of diversity jurisdiction in the article III circuit courts. Cf. National Mut. Ins. Co. v. Tidewater Transfer Co., 337 U.S. 582 (1949) (revisiting the issue with respect to District of Columbia citizens). As is explained below, that result could lead to the conclusion that Congress does not have the power under article III to authorize territorial tribunals to hear clains by or against territorial citizens that are substantively founded on state law. If true, the result is interesting, and perhaps unfortunate, but results alone are of course not decisive for formalists.

They were, however, apparently decisive for Chief Justice Marshall. In Seré v. Pitot, 10 U.S. (6 Cranch) 332 (1810), Marshall declared that a territorial court in Orleans was capable of hearing a simple debt action brought by aliens against citizens of Orleans, despite the fact that article III provides for federal court jurisdiction over controversies between state citizens and foreign subjects but not betwecn territorial citizens and foreign subjects. See U.S. CoNST. art. III, $\S 2$, cl. 1 ("[t] he judicial Power shall extend . . . to Controversies . . . between a State, or the Citizens thereof, and foreign States, Citizens or Subjects"). "[T]he idea," said Marshall, "that the constitution restrains congress from giving the court of the territory jurisdiction over a case brought by or against a citizen of the territory . . . is most clearly not to be sustained . . . ." Seré, 10 U.S. (6 Cranch) at 337. Marshall's reasoning was terse, conclusory, and alarmist:

Let us inquire what would be the jurisdiction of the [territorial] court, on this restricted construction [limiting its jurisdiction to the nine heads specified in article III]?

It would have no jurisdiction over a suit brought by or against a citizen of the territory, although an alien, or a citizen of another state inight be a party.

It would have no jurisdiction over a suit brought by a citizen of one state, against a citizen of another state, because neither party would be a citizen of the "state" in which the 
This odyssey has clear implications for the problem that Sakamoto presents to formalists: If Congress can create queer-duck territorial judges who need not conform to the structural requirements of article III, why can't it also create queer-duck territorial executives who need not conform to the structural requirements of article II? Or, to turn the question around, doesn't a claim that queer-duck territorial executives are unconstitutional simply ignore at least 160 , and perhaps 200 , years of constitutional history concerning territorial tribunals?

\section{B. Article II and Territorial Executives}

I suspect that most formalists would find the prospect of ignoring 200 years of constitutional history concerning territorial tribunals quite appealing. They may, lowever, be less enthusiastic about the logical consequences of applying formalism to the elected officials in the executive branches of territorial governments. Consider again the elected governor of Guam, who formalists would say is disabled from executing the laws of the United States. The Organic Act of Guain charges the governor with the faithful execution of federal laws and "the laws of Gualn"246 enacted by the territorial legislature. Are these two distinct charges, or one? If Guainanian laws are in fact federal laws, then even territorial laws of a purely local character, enacted by local legislatures, must be administered by presidential appointees rather than by democratically elected or locally appointed and responsive officials.

The question whether territorial laws are necessarily laws of the Umited States under article II is starkly reminiscent of the battle fought over the authority of the second Bank of the United States to sue in federal court, which the Supreme Court resolved in the Bank's favor in the companion cases of Osborn v. Bank of the United States ${ }^{247}$ and Bank of

court sat. Of what civil causes, then, between private individuals, would it have jurisdiction? Only of suits between an alien and a citizen of another state, who should be found in Orleans.

Id. As was often his wont, Marshall clearly overstated his case. The suits that concerned him could all be entertained by article III courts in the territories whenever the claim is substantively founded on territorial law (as was evidently true of the clain in Sere), since the case would then "arise under" the laws of the United States. See infra text accompanying notes 257-69 (explaining why territorial laws are federal laws for purposes of article III). A jurisdictional gap is possible only with respect to claims founded on state law. And even in such cases, the territorial court must at least apply a territorial choice of law rule in order to establish that state law governs the claim, which is arguably enough to satisfy the Constitution's "arising under" language.

Marshall's conclusion that the jurisdiction of territorial courts is not limited by the terms of article III was perhaps the one clear precursor of American Insurance Co. in the first quarter of the nineteenth century. As in the latter case, the constitutional discussion in Seré was dictum, as Marshall had earher held that Seré's clain was in any event exeluded from the territorial court's jurisdiction by statute. See Seré, 10 U.S. (6 Cranch) at 334-36.

246. 48 U.S.C. $\S 1422$ (1988).

247. 22 U.S. (9 Wheat.) 738 (1824). 
the United States v. Planters' Bank. ${ }^{248}$ Congress created the Bank with the authority "to sue and be sued . . . in any Circuit Court of the United States."249 In Osborn, the Court concluded that this statute conferred subject niatter jurisdiction on the federal courts, ${ }^{250}$ even for simple contract actions brought by the Bank. ${ }^{251}$ The next question was whether any of the sources of federal jurisdiction specified in article III could sustain so expansive a statutory grant. The only possible candidate was article III's "arising under" clause. ${ }^{252}$ Chief Justice Marshall found this source adequate, entploying reasoning that could be used almost verbatim in connection with territorial governments:

The [bank's] charter of incorporation not only creates it, but gives it every faculty which it possesses. The power to acquire rights of any description, to transact business of any description, to inake contracts of any description, to sue on those contracts, is given and measured by its charter, and that charter is a law of the United States. This being can acquire no right, make no contract, bring no suit, which is not authorized by a law of the United States. It is not only itself the nere creature of a law, but all its actions and all its rights are dependant on the same law. Can a being, thus constituted, have a case which does not arise literally, as well as substantially, under the law? ${ }^{253}$

Marshall's reasoning, while far fronı conpelling, is nonetheless persuasive, at least when limited to federal instrunientalities. While the text of article III can sustain a narrower reading, ${ }^{254}$ it can also sustain Marshall's, which better fits the text's evident purposes. As Osborn itself deinonstrates, federal instrunientalities can receive rough treatment at the hands of the states, ${ }^{255}$ and $\mathrm{in}$ order to protect then it nay be necessary to provide a hospitable judicial fornm for resolving even the most nunndane common law questions. ${ }^{256}$

248. 22 U.S. ( 9 Wheat.) 904 (1824).

249. Act of Apr. 10, 1816, ch. 44, § 7, 3 Stat. 266, 269.

250. See Osborn, 22 U.S. ( 9 Wheat.) at 817-18. That conclusion was not inevitable, though its correctness is of no concern here. See Currie, supra note 124, at 695 n.302 (noting the Court's earlier contrary conclusion in Bank of the United States v. Devaux, 9 U.S. (5 Cranch) 61, 85-86 (1809)).

251. This was precisely the question at issue in Planters' Bank, though Chief Justice Marshall addressed it in Osborm. See Osbom, 22 U.S. (9 Wheat.) at 823-26.

252. U.S. CONST. art. III, $\S 2$, cl. 1 (extension of federal judicial power to "all Cases, in Law and Equity, arising under ... the Laws of the United States").

253. Osborn, 22 U.S. ( 9 Wheat.) at 823.

254. Courts have in fact read the "arising under" language in the general federal question statute, 28 U.S.C. $\$ 1331$ (1988), inore narrowly than Marshall read the Constitution in Osborn. See M, REDISH, supra note 124, at 64 . This narrow reading can be correct as a matter of statutory interpretation without calling into question Marshall's constitutional analysis.

255. In Osborn, the state of Ohio had soaked the Bank of the Uirited States for $\$ 100,000$ in taxes, at a time when that was real money (both literally and figuratively). See Osborn, 22 U.S. ( 9 Wheat.) at 740-41.

256. See Currie, supra note 124 , at 697. 
If all cases involving federal instrumentalities necessarily "arise under" the laws of the Uinted States, so inust all cases involving territorial goveruments-as Samuel Jones inaintained in United States $v$. More. ${ }^{257}$ Like the Bank of the Umited States, territorial governments are "entirely the creation of Congress."258 All their powers flow froin the relevant orgairic statutes; they cannot so mucl as enter into contracts without congressional authorization. It would seem that all their lawsindeed, all their acts and decisions-arise under the laws of the United States. ${ }^{259}$

The Osborn Court's interpretation of article III, if correct, has imphications for article II as well. If cases arising under territorial stat-

257. See supra text accompanying note 179.

258. Umited States v. Wheeler, 435 U.S. 313, 321 (1978).

259. This conclusion led to one of the more entertaining aspects of American Insurance Co. v. 356 Bales of Cotton, 26 U.S. (1 Pet.) 511 (1828). The insurance companies' statutory arguments against the jurisdiction of the salvage court, see supra text accompanying notes 228-32, turned in large measure on whether the cause was one "arising under" the laws of the United States within the meaning of the statute establishing the jurisdiction of the Florida superior courts. If the cause did "arise under" federal law, then the provision of the Organic Act giving the superior courts the same jurisdiction as federal district courts in such cases would apply. Additionally, since the district courts had exclusive jurisdiction over admiralty cases, it could then at least be argued that the territorial admiralty jurisdiction was vested exclusively in the superior courts. The insurance companies cited Osborn and argued to Justice Johnson in the circuit court that all activities of the Florida courts indeed presented cases arising under federal law, just as did all activities of the Bank of the Umited States. See American Insurance Co., 26 U.S. (1 Pet.) at 520 n.*. Justice Johnson, who had been the lone dissenter in Osborn, see 22 U.S. ( 9 Wheat.) at 871 (Johnson, J., dissenting), gave the following memorable response:

I have taken a week to reflect upon this question alone, and I cannot withhold from the gentleman, who argued the cause for the libelants, an acknowledgment, that I have not been able to draw any lime of discrimination, between this and the decided cause, which satisfies my mind. Yet, I am thoroughly persuaded that the learned men who decided that cause, never contemplated that such an application would have been given of their decision. I am liappy in tlie prospect that this cause will finally be disposed of elsewhere, not doubting, that the mental acumen of those who decided the other, will be found fully adequate to distinguisl or reconcile tlie two cases, on grounds which have escaped my reflections. At present, I must content myself with observing, that it is too much to require of a Court, upon mere analogy, to sustain an argument, tliat not only proves too mucli, if it proves any thing, but wlich leads, in fact, to positive absurdity.

American Insurance Co., 26 U.S. (1 Pet.) at 521-22 n.* (circuit court opinion of Jolinson, J.).

In fact, Justice Johnson did have, and indeed relied upon, a perfectly good basis for distinguisling American Insurance Co. from Osborn; lie simply could not pass up an opportunity to tweak the Osborn majority. (The majority did not respond to this cliallenge, or indeed to the insurance compames' argument, when American Insurance Co. reached the Supreme Court.) Osborn involved the interpretation of article III, while American Insurance Co. involved the interpretation of a statute. If the statute vesting jurisdiction in tlie superior courts of Florida had used the words "arising under" in their full constitutional sense (as construed by Osborn), then it would lave been meaningless for that statute also either to grant or to limit the jurisdiction of the Florida territorial courts by reference to the jurisdiction of the Kentucky court. Eacls and every case arising in the Florida territory would lave arisen under federal law, which is a most implausible interpretation of the terms of the organic act. See American Insurance Co., 26 U.S. (1 Pet.) at 520 n.*. The same reasoning supports the result in Puerto Rico v. Russell \& Co., 288 U.S. 476, 483-85 (1933) (despite lrolding in Osborn with regard to federal corporations, suit leeld not to arise under United States law merely because it involves a territorial government whose existence derives from an act of Congress). 
utes enacted by local legislatures are within the constitutional jurisdiction of the federal courts under article III, by implication one could conclude that the execution of those statutes is within the constitutional jurisdiction of the President under article II. ${ }^{260}$ If rules promulgated by federal administrative agencies can be enforced only by appropriately appointed "officers of the United States," 261 it seems obvious that territorial statutes can be enforced only by properly appoimted officers of the Umited States, not by locally elected or appointed officials. ${ }^{262}$

This issue was raised by the facts of Snow v. United States ex rel. Hempstead, ${ }^{263}$ though neither the parties nor the Court directly addressed it. The 1850 Organic Act creating the Utah territorial governnient directed the President to appoint an attorney for the territory, ${ }^{264}$ but did not specify that officer's duties. The statute also created an elected territorial legislature ${ }^{265}$ with power over "all rightful subjects of legislation, consistent with the Constitution of the United States and the provisions of [the organic act]." ${ }^{266}$ Pursuant to this authority, the Utah Legislature in 1852 provided for an attorney general for the territory, to be elected by the legislative assembly. ${ }^{267}$ The attorney general was given authority, aniong other things, to prosecute persons accused of crimes "in cases arising under the laws of the Territory."268 The territorial statute obviously conteniplated a division of authority between the presidentially appointed and territorially elected attorneys: the latter would handle purely territorial affairs, such as prosecuting violations of territorial criminal laws; the former would attend to "cases in which the government of the United States is concerned," ${ }^{, 269}$ such as those involving federal crimes.

This two-tiered prosecutorial system worked without incident for twenty years, as it had in other territories. ${ }^{270}$ In 1870, however, Charles Heinpstead, the presidentially appointed Umited States Attorney, brought a quo warranto action aganist Zerubbabel Snow, the territorial attorney general, claiming exclusive authority to prosecute all criminal actions brought in the courts of the territory, whether the actions

260. U.S. CoNST. art. II, $\S 3$ ("[The President] shall take Care that the Laws be faithfully executed ....").

261. See Buckley v. Valeo, 424 U.S. 1, 138-39 (1976) (per curiam).

262. See supra text accompanying notes 59-63.

263. 85 U.S. (18 Wall.) 317 (1873).

264. See Act of Sept. 9, 1850, ch. 51, §§ 10-11, 9 Stat. 453, 456.

265. See id. $\S 4,9$ Stat. at 454.

266. Id. $\S 6,9$ Stat. at 454 .

267. Snow, 85 U.S. (18 Wall.) at 321.

268. Id. at 318 (emphasis in original). The territorial statute also provided for the election of district attorneys with similar authority over crimes in their districts. See id.

269. Id. at 322.

270. See id. at 321. 
involved congressional or territorial laws. ${ }^{271}$ Snow conceded Hempstead's exclusive prosecutorial authority "in any case wherein the United States of America is a party, or wherein the offence is against the laws of the Uinited States," 272 but he insisted on his "right and . . . duty of conducting the business in the courts in cases where the Territory is a party or is interested."273 The Utah Supreme Court ruled in favor of Heinpstead, for reasons that reinain unclear. ${ }^{274}$ The Uinited States Supreine Court reversed, construing the organic act to permit locally appointed officials to prosecute local crimes. ${ }^{275}$

Although the opinion in Snow contains an offhand reference to the Constitution, ${ }^{276}$ it is clear that the Court and the parties thought the case presented only an issue of statutory interpretation. ${ }^{277}$ As so often happens in territorial cases, however, the Court danced on the edge of more important questions. The Uinted States represented "that there ha[d] becn a very common, if not a universal, custom in Territories to create Territorial prosecuting officers to prosecute ... [local] offences."278 The Court aceepted that representation, and its reading of the organic act was clearly influenced by its perception of a "long usage" of a dual prosecutorial system in the territories. ${ }^{279}$ Along the way, it made some observations about this tradition that are-apart from their conclusionstrikingly reminiscent of Sainuel Jones' irrepressible formalistic argument in United States v. More that all territorial actions are in truth the actions of the federal government. ${ }^{280}$

It must be confessed that this [dual prosecutorial] practice exhibits

271. See Transcript of Record at 5, Snow, 85 U.S. (18 Wall.) 317 (No. 424).

272. Id. at 6.

273. Id. at 7 .

274. I have been unable to locate the Utah Supreme Court's opinion. The statenient of the case in the United States Reports says only that "[t]he Suprenie Court of the Territory, assuming that the Suprene Court and the District Courts of Utah were courts of the United States, were of the opinion that the attorney of the United States was the proper person; and adjudged accordingly." Snow, 85 U.S. (18 Wall.) at 319. The sparsc record before the United States Suprene Court provides no elaboration. Whatever the Utah Suprene Court might have meant, its assumption that Utah's territorial courts were courts of the United States was rejected in Clinton v. Englebrecht, 80 U.S. (13 Wall.) 434, 447 (1872). Snow's counsel, in a one-paragraph brief, sought what amounted to summary reversal on the strength of Clinton. See Brief for Plaintiff in Error, Snow, 85 U.S. (18 Wall.) 317 (No. 424). The United States filed a three-page brief which made no reference to the status of the Utah territorial courts. See Brief for the United States, Snow (No. 424).

275. See Snow, 85 U.S. (18 Wall.) at 322.

276. See id. ("The power given to the [Territorial] legislature ... extends to all rightful subjects of legislation consistent with the Constitution and the organic act itself. And there seens to be nothing in either of these instruments which directly conflicts with the Territorial law.").

277. See id. at 321 ("The question is ... whether the act of the Territorial legislature was authorized by the organic act."); Brief for the United States at 2, Snow (No. 424) (characterizing the case strictly in statutory terms).

278. Brief for the United States at 3, Snow (No. 424).

279. See Snow, 85 U.S. (18 Wall.) at 322.

280. See supra text accompanying note 179. 
soinewhat of an anoinaly. Strictly speaking, there is no sovereignty in a Territory of the United States but that of the United States itself. Crimes committed therein are committed against the government and dignity of the United States. It would seen that indictments and writs should regularly be in the naine of the United States, and that the attorney of the United States was the proper officer to prosecute all offences. But the practice has been otherwise, not ouly in Utah, but in other Territories organized upon the saine type. ${ }^{281}$

One can readily imagine a formalist nodding in approval at the first four sentences of this discussion, expecting it to end with something like, "Because the Umited States is the only true sovereign in the territories, the execution of territorial laws must be treated like execution of any other laws of that sovereign, and can therefore be undertaken only by properly appointed officers of the United States." No such luck: "The practice has been otherwise."

This Article's starting point was the evident unconstitutionality of conferring authority to execute federal laws on popularly elected territorial officials. While the long tradition of presidential appomtment of territorial governors ${ }^{282}$ minimized these problems for inuch of the nation's history, it is clear froin Snow that cracks in the structure of territorial executive activity had appeared even before the first election of a territorial governor was authorized in 1947. Elected officials have had important executive functions in the territories for a long time. If one were to conclude that territorial officials cannot be elected but rather inust be appointed $\mathrm{n}$ 1 accordance with article II ni order constitutionally to exercise their authority, it would be a conclusion of no small monent. Furthermore, the conclusion does not seem to have occurred to any hitigants: to the best of iny knowledge, the constitutionality of having locally elected or appointed prosecutors enforce territorial laws has never been challenged. Yet if formalists are correct that territorial laws are laws of the Umited States and thus should be executed by persons appointed in conformity with the appointnients clause, then for many decades persons in the territories have been imprisoned-and even executed-for alleged crimies prosecuted by usurpers, ${ }^{283}$ and Congress' laudable desire to bring

281. Snow, 85 U.S. (18 Wall.) at 321.

282. See supra text accompanying note 85 .

283. This calls to mind the comments of Justice Catron in Dred Scott, affirming the power of Congress to govern territories under article IV:

It is due to myself to say, that it is asking much of a judge, who has for nearly twenty years been exercising jurisdiction, from the western Missouri line to the Rocky Mountains, and, on this understanding of the Constitution [that Congress has power under article IV to govern territories], inflicting the extreme penalty of death for crimes committed where the direct legislation of Congress was the only rule, to agree that he had been all the while acting in mistake, and as an usurper.

Dred Scott v. Sandford, 60 U.S. (19 How.) 393, 522-23 (1857) (Catron, J., concurring). 
some measure of democracy and self-government to the territories through local elections is constitutionally forbidden.

\section{Article I and Territorial Legislatures}

The modern statutes permitting territorial citizens to elect their own governors reflect a general American commitment to democratic selfgovernment. That commitment has influenced policy concerning the territorial lawmaking power since the nation's founding. The Northwest Ordimance of 1787 provided for a (partially) elective legislative assembly as soon as the territorial population was large enough to make an election practicable, ${ }^{284}$ and elected legislatures with broad power over local affairs ever since have been a staple of territorial administration. ${ }^{285}$ The reasons for this practice are obvious. In territories viewed as candidates for stateliood, self-government through an elected legislature helps prepare the population for the responsibilities of statehood and establishes laws and institutions to serve as foundations for the new order upon admission to the Umion. In territories with no prospects of achieving stateliood, limited self-government can prepare the people for nationhood if the territory is ultimately granted full independence, as liappened witlı the Philippines. Finally, even if self-government serves no further purpose, deinocratic theory suggests that soine measure of self-government through a representative assembly is distinctly preferable to rule by a distant Congress, President, or cabinet secretary.

To a formalist, however, locally elected legislatures are even inore clearly unconstitutional than are elected governors. The enactment of territorial laws looks for all the world hike the exercise of legislative power. If territorial laws are laws of the Umited States for purposes of articles III and II, there is no evident reason why they sliould not also be considered laws of the United States for purposes of article I. In other words, since territorial governments are wholly the creations of the federal sovereign, the legislative power they exercise must be, as Samuel

284. An Ordinance for the Government of the Territory of the United States north-west of the river Ohio (1787), reprinted at 1 Stat. 50, 51 n.(a) (1789).

285. See Snow, 85 U.S. (18 Wall.) at 320 ("It is, indeed, the practice of the government to invest these dependencies with a limited power of self-government as soon as they have sufficient population for the purpose."); Clinton v. Englebrecht, 80 U.S. (13 Wall.) 434, 441 (1872) ("The theory upon which the various governments for portions of the territory of the United States have been organized, has ever been that of leaving to the inhabitants all the powers of self-governinent consistent with the supremacy and supervision of National authority ....").

Nonetheless, the practice of allowing self-government has not been uniform. See Act of May 17, 1884, ch. 53, $\S 9,23$ Stat. 24, $26-27$ (explicitly forbidding a legislative assembly in Alaska); Act of Mar. 3, 1823, ch. 28, § 5, 3 Stat. 750, 751 (providing for a legislature in Florida to be appointed by the President); Act of Mar. 26, 1804, ch. 38, $\S 4,2$ Stat. 283, 284 (providing for a legislature in Orleans to be appointed by the President). 
Jones argued in United States $v$. More, ${ }^{286}$ the legislative power of the United States. The federal legislative power, however, is "vested in a Congress of the United States"287 and cannot be delegated to other actors. ${ }^{288}$ Thus, a statute granting a territorial legislature power over "all subjects of legislation of local apphication"289 is a blatant violation of the nondelegation principle. ${ }^{290}$

Even if elected territorial legislatures do not exercise legislative power as defined in the Constitution, they are unconstitutional for other reasons. If their power is not legislative, the only other plausible conclusion is that they exercise executive power by effectuating their congressionally enacted organic statutes. Reineinber, though, that any federal officials who execute congressional statutes inust be constitutionally appointed officers of the United States, and elected territorial legislators are clearly not so appointed. Hence, whether their powers are viewed as legislative or executive, territorial legislatures cannot constitutionally be elected by the people of their territory. If they can properly exist at all, they inust be subject to appointnient and direction by appropriate officials of the federal government.

The only evident response to this analysis is to concede the point with respect to the District of Coluinbia but to argue that the peculiar phrasing of the territories clause permits a different result with respect to other territories. The District clause empowers Congress to "exercise exclusive legislation in all Cases whatsoever"291 concernimg the District of Coluunbia. The territories clause, by contrast, speaks of Congress'

286. See supra text accompanying note 179.

287. U.S. CoNST. art. I, $\S 1$ (emphasis added).

288. A full defense of this principle would require a separate article. The burden of proof, however, should be on those who maintain that delegation is pernissible. The Constitution prescribes in great detail the processes for electing legislators, see U.S. CoNST. art. I, $\S 2$, cl. 1-4; id. $\S 3$, cl. $1-3 ;$ id. $\S 4$, cl. 1 ; id. $\S 5$, cl. 1 , and for enacting legislation, see id. $\S 4, \mathrm{cl} .2$; id. $\S \S 5,7$. Little reason would remain to pay such careful attention to the selection and operation of the legislative branch if Congress could simply shift responsibilities to other actors through delegation. There remains the formidable task of distinguishing the legislative from the executive power, but $I$ ain satisfied that anything fairly characterized as the forner must be exercised exclusively by the constitutionally prescribed legislative institutions.

289. 48 U.S.C. $\$ 1423 \mathrm{a}$ (1988) (describing power of Guananian legislature).

290. Such a statute would seemingly fail even the Supreme Court's highly deferential test for delegation of power. See Skinner v. Mid-America Pipeline Co., 109 S. Ct. 1726, 1731 (1989) ("[S]o long as Congress provides an administrative agency with standards guiding its actions such that a court could 'ascertain whether the will of Congress has been obeyed,' no delegation of legislative authority trenching on the principle of separation of powers has occurred.") (quoting Yakus v. United States, 321 U.S. 414, 426 (1944)). Confining the authority of a territorial legislature to subjects of "local application" no more constitutes a "standard" than would confining the otherwise unconstrained rulemaking authority of an administrative agency to matters involving interstate commerce.

291. U.S. CoNST, art. I, $\S 8, \mathrm{cl} .17$ (emphasis added). 
power to "make all needful rules and regulations respecting"292 the territories. Conceivably, one could argue that because the latter language plainly contemplates the enactment of framework statutes for the territories rather than detailed congressional legislation, it is an exphicit authorization for the delegation of power to territorial administrators.

The conclusion, however, does not follow from the premise. One must remember that the "territories clause" is actually the "territory or other property" clause, authorizing Congress to enact rules and regulations "respecting the territory or other property belonging to the Umited States."293 The inclusion of "other property" in the clause is a critical eleinent of context. Congress surely need not enact a detailed legislative code for the purchase, use, and disposition of every item of property owned or utilized by the federal government, from public lands to office supphes. Framework statutes suffice for this purpose, allowing administrators the discretion to fill the necessarily large gaps in the resulting statutory scheme. This arrangenent, though, is constitutionally permissible with respect to public lands and office supplies not because article IV somehow trumps the nondelegation doctrine, but because gap-filling in this context is execution rather than legislation. Hence, the most to be drawn from the language of article IV is that appointed territorial legislatures might be permissible (though even this is doubtful); ${ }^{294}$ elected territorial legislatures are clearly impermissible.

While the constitutional defects of elected territorial legislatures may be apparent to formalists, they did not trouble the framers or early constitutional scholars. James Madison took it for granted in The Federalist that the inhabitants of the District of Columbia would be given the power of local self-government. ${ }^{295}$ Although St. George Tucker, writing in 1803, disputed Madison's assumption that a local legislature for the District of Columbia would not offend the Constitution, ${ }^{296}$ his doubts did not gam currency, and Joseph Story was able to

292. Id. art. IV, \& 3, cl. 2 (emphasis added).

293. Id.

294. Appointed legislatures remain questionable, because territorial lawmaking looks much more like legislation than does the promulgation of regulations governing purchases of pads and pencils. But the point is concededly open to debate.

295. See The Federalist No. 43, at 272-73 (J. Madison) (C. Rossiter ed. 1961) ("[A] municipal legislature for local purposes, derived from their own suffrages, will of course be allowed [the citizens of the district] ...."). The example of the District of Columbia is instructive, because Congress' legislative power over the District is specifically designated by the Constitution as "exclusive." See U.S. CoNST. art. I, § 8, cl. 17. If Congress can nonetheless delegate legislative authority to a District of Columbia legislature, there cannot possibly be a valid objection to similar delegations to other territorial governments.

296. See 1 St. George TuCker, Blackstone's Commentaries App. 278 (Philadelphia 1803), reprinted in 3 THE Founders' Constitution 230 (P. Kurland \& R. Lerner eds. 1987) [heremafter Founders' CoNSTITUTION]:

It has been said, that it was in contemplation to establish a subordinate legislature, with a 
dismiss them cavalierly thirty years later. ${ }^{297}$

Nor has the Supreme Court been troubled by the apparent constitutional defects of territorial legislatures. The first serious constitutional challenge to the authority of a territorial legislature ${ }^{298}$ reached the Court in 1904 in Dorr v. United States. ${ }^{299}$ The Philippines at that time were governed by the United States Philippime Commission, a presidentially directed body exercising local legislative authority. ${ }^{300}$ The Commission had enacted a criminal libel statute, ${ }^{301}$ under which Dorr was prosecuted and convicted. Dorr's principal constitutional challenge to his conviction was the fact tliat lie had been deired a jury trial. ${ }^{302}$ The Suprenie Court invoked the territorial incorporation doctrine ${ }^{303}$ and held that the right to jury trial did not of its own force extend to the Philippines. ${ }^{304}$ Dorr also argued that the libel statute was invalid because Congress could not delegate legislative autliority to the Philippine Commission that had enacted it. The Court brushed this claim aside nits concluding paragraph:

The [libel statute] was one of the laws of the Philippine Commission, passed by that body by virtue of the authority given the President under ... [the governing organic statute]. The right of Congress to authorize a temporary government of this character is not open to question at this day. The power has been frequently exercised and is too well settled to

governor to preside over the district. But it seems highly questionable whether such a substitution of legislative authority is compatible with the constitution; unless it be supposed that a power to exercise exclusive legislation in all cases whatsoever, comprehends an authority to delegate that power to another subordinate body. If the maxim be sound, that a delegated authority cannot be transferred to another to exercise, the project here spoken of will probably never take effect.

297. See 3 J. STORY, Commentaries ON THE CoNSTITUTION $§ 1218$ (Boston 1833), reprinted in 3 FoundERs' CONSTITUTION, supra note 296, at 237 ("the corporations of the three cities within [the District of Columbia's] limits possess and exercise a delegated power of legislation under their charters, granted by congress, to the full extent of their municipal wants, without any constitutional scruple, or surmise of doubt").

298. The words "serious" and "constitutional" are both important qualifiers. A less serious coustitutional challenge was advanced in American Insurance Co. v. 356 Bales of Cotton, 26 U.S. (1 Pet.) 511 (1828). In the course of arguing that admiralty jurisdiction in the territories could only be vested in courts created by Congress, counsel for the insurance companies observed, "It is said that Congress has given to the territorial legislature all the rights of legislation they have. Legislative powers cannot be delegated. Delegatus non potest delegare" Id. at 540 . There were no prior or subsequent mentions of this argument, and it seems to have been regarded by all concerned as a make-weight, at best.

On the other hand, serious statutory challenges to particular exercises of territorial legislative authority were common prior to 1904. See District of Columbia v. John R. Thompson Co., 346 U.S. 100,106 \& n.5 (1953) (collecting cases).

299. 195 U.S. 138 (1904).

300. See Act of July 1, 1902, ch. 1369, § 1, 32 Stat. 691, 691-92.

301. See Dorr, 195 U.S. at 150-51 (reproducing the entire statutc).

302. See id. at 139.

303. See $i d$. at 144, 148; see also supra text accompanying notes $93-120$ (discussing development and application of the incorporation doctrine).

304. Dorr, 195 U.S. at $148-49$. 
require further discussion. ${ }^{305}$

That was the full extent of the Court's discussion; it settled the matter by history, not analysis.

The issue surfaced twice more $\mathrm{m}$ this century, $\mathrm{m}$ connection with elected rather than appointed legislatures, and each time led to the same result as in Dorr. In Cincinnati Soap Co. v. United States, ${ }^{306}$ soap manufacturers challenged the validity of a tax on domestic processing of coconut oil produced in the Philippimes. All funds collected under the tax were to be paid over to the Philippime treasury, ${ }^{307}$ with no congressional restrictions on or mstructions concerning their use. The soap manufacturers argued that Congress could not delegate its authority to determine spending priorities to the (by that time elective) Philippine legislature. ${ }^{308}$ The manufacturers protested, on general nondelegation grounds, the absence of standards to guide the conduct of the delegate. ${ }^{309}$ They also argued, albeit im a wholly conclusory fashion, that even with proper standards the Philippime government could not receive a delegation of the spending power. ${ }^{310}$ The Court upheld the tax, flatly denying that Congress is required to provide standards to govern the use of general, lump-sum appropriations. ${ }^{311}$ More significantly, the Court turned the soap companies' second argument on its head, declaring that even if an appropriation without standards for its expenditure would ordinarily be unlawful, it is permissible when Congress delegates authority to a territorial government. ${ }^{312}$ "In dealing with the territories," the Court wrote, "Congress . . . is not subject to the same restrictions which are iniposed m respect of laws for the Umited States considered as a political body of states in union." 313 If Congress can create local legislatures with the power to tax, as the Court assumed it could, it must also be able to create them with the power to spend. ${ }^{314}$

The last challenge to a territory's legislative power came in 1953 in District of Columbia $v$. John R. Thompson Co. ${ }^{315}$ The defendant con1pany was criminally prosecuted im the District of Colunibia for violating

305. Id. at 153 (citation omitted).

306. 301 U.S. 308 (1937).

307. Revenue Act of 1934 , ch. $277, \S 6021 / 2,48$ Stat. $680,763-64$. By this time, Congress had granted the Philippines a very substantial degree of local autonomy. See generally Philippine Independence Act, ch. 84, 48 Stat. 456 (1934).

308. Cincinnati Soap Co., 301 U.S. at 321.

309. Brief of Petitioner Cincinnati Soap Co. at 58-59, Cincinnati Soap Co. (No. 659); Brief for Petitioner Haskins Bros. \& Co. at 48-49, Cincinnati Soap Co. (No. 687); Reply Brief for Petitioner Haskins Bros. \& Co. at 15-16, Cincinnati Soap Co. (No. 687).

310. Brief for Petitioner Haskins Bros. \& Co. at 47, 49, 52, Cincinnati Soap Co. (No. 687).

311. Cincinnati Soap Co., 301 U.S. at 321-22.

312. Id. at 322-23.

313. Id. at 323 (citing Dorr v. United States, 195 U.S. 138, 140, 142 (1904)).

314. See id.

315. 346 U.S. 100 (1953). 
a local ordinance prohibiting racial discrimination by restaurateurs. By 1953, a frontal challenge to the District of Columbia's legislative power clearly would have been futile. As a result, the defendant sought to distinguish between the power to enact municipal and pohice regulations, which it conceded Congress could delegate to the District, and the power to enact legislation, which the defendant maintained was exclusively vested in Congress. ${ }^{316}$ The Court rejected the distinction, holding that Congress could delegate to the District, and to other territories, all lawmaking powers that it could itself exercise. ${ }^{317}$

The final tally concerning the three branches of territorial government is thus a rout: history 3 , formalism 0 .

\section{Postscript: Article IV and the Power to Govern Territories}

The discussion thus far has assunied that the federal governinent's power to administer territories is vested in Congress by specific clauses of the Constitution: in the case of the District of Colunibia, the pertiment clause authorizes Congress "[t]o exercise exclusive Legislation in all Cases whatsoever, over such District"; ${ }^{318}$ in the case of other territories, the relevant clause empowers Congress to "make all needful Rules and Regulations respecting the Territory or other Property belonging to the Umited States."319 Other clauses may come imto play, however. Consider a military occupation of foreigu soil during wartime. Congress does not pass statutes for the administration of the conquered territory, whose boundaries may fluctuate from day to day. Rather, the President, through military commanders, admimisters the occupied territory as part of the war effort. In one sense, the occupied ground is plainly "territory" of the Umited States, in that American governmental officers will claim rightful authority to govern or administer that occupied land, ${ }^{320}$ even if only for a short time. It is less clear whether the occupied land is "territory belonging to the Umited States" within the meaning of article IV of the Constitution, granting Congress the power to govern such lands. Even in the absence of congressional authority to govern, however, some power of administration seems to be constitutionally vested in the executive branch by virtue of the President's article II function as

316. Brief for Respondent at 22, District of Columbia v. John R. Thompson Co., 346 U.S. 100 (1953) (No. 617) ("It is settled that while the Congress may delegate to the Government of the District of Columbia the power to make municipal and police regulations, Congress, under the Constitution having exclusive legislative power over the District of Columbia, cannot delegate to the District the power to enact legislation.").

317. See John R. Thompson Co., 346 U.S. at 106-09.

318. U.S. ConsT. art. I, § 8, cl. 17.

319. Id. art. IV, § 3, cl. 2.

320. See Fleming v. Page, 50 U.S. (9 How.) 603, 615-17 (1850) (military occupation of a foreign territory does not make that territory part of the United States without congressional action, but the President can administer the occupied land as part of the war effort). 
"Commander in Chief of the Army and Navy of the United States." 321 Thus, a formalist would probably conclude that the power to administer territories is twofold: during United States military occupation of territories, the President's war powers provide authorization for territorial governance under article II, while the regular administration of territories belongs to Congress under the territories clause of article IV..$^{322}$

The federal courts have never accepted this analysis, although they have had considerable trouble articulating an alternative one. The issue was first discussed by the Suprene Court in 1810 in Seré v. Pitot, ${ }^{323}$ in which the Court unqualifiedly affirmed the power of Congress to estabhish territorial governments. ${ }^{324}$ The Court was less forthcoming, however, about the source of that power:

The power of governing and of legislating for a territory is the inevitable consequence of the right to acquire and to hold territory. Could this position be contested, the constitution of the United States declares that "congress shall have power to dispose of and make all needful rules and regulations respecting the territory or other property belonging to the United States."325

This passage implies that the power to govern territories would exist even in the absence of the territories clause, based on a necessary inference fronl the power of territorial acquisition. The problein is that the Constitution does not contain an explicit power of territorial acquisition, a fact that much concerned President Jefferson and nembers of Congress when they were considering the Louisiana Purchase. ${ }^{326}$ In American Insurance Co. v. 356 Bales of Cotton, ${ }^{327}$ Chief Justice Marshall nonetheless found a source for the "right to acquire and to hold territory," repeating his view that the power to govern territories could flow from

321. U.S. CONST. art. II, $\S 2$, cl. 1 . Whether Congress could, if it so desired, participate in the administration of occupied territory under the "necessary and proper" clause, id. art. $I, \S 8, \mathrm{cl} .18$, is a question for another time.

322. The interplay between these powers raises fascinating questions when one considers the possibility of an interregnum. Suppose that the President is administering occupied territory during wartime. Then the war ends, the countries sign a treaty of peacc, and the occupied territory is formally ceded to the United States. Under a formalist analysis, responsibility for governance now shifts to Congress under the territories clause. But what if Congress does not act? Does the executive branch - or perhaps the territorial population-have some residual or inherent governing authority? Or do we have a state (or territory) of anarchy? This precise question actually arose and was litigated to a final judgment in connection with California, in Cross v. Harrison, 57 U.S. (16 How.) 164 (1854) (civil government established by President continued to function until Congress legislated otherwise). See also Santiago v. Nogueras, 214 U.S. 260, 265-66 (1909) (same). I plan to explore the legal and political issues raised by Cross $v$. Harrison in a subsequent article.

323. 10 U.S. (6 Crancli) 332 (1810).

324. See id. at 337 ("[W]e find congress possessing and exercising the absolute and undisputed power of governing and legislating for the territory of Orleans.").

325. Id. at 336-37 (quoting U.S. CoNST. art. IV, § 3, cl. 2).

326. See The INSUlar CaSes, supra note 102, at 125-30, 152-64.

327. 26 U.S. (1 Pet.) 511 (1828). 
either the territories clause or the right to acquire territory, ${ }^{328}$ and locating the latter right in the war and treaty powers. ${ }^{329}$

In 1840, the Court in dictum appeared to ground the power to govern territories squarely in article IV. ${ }^{330}$ Less than twenty years later, however, in Dred Scott v. Sandford, ${ }^{331}$ a plurality of the Court in dictum grounded the power to govern acquired territories solely in the right of acquisition, ${ }^{332}$ concluding that the territories clause applied only to the territory held in common by the states immediately prior to ratification of the Constitution. ${ }^{333}$ That resolution, if it conld ever have been called that, did not last long. In National Bank v. County of Yankton ${ }^{334}$ in 1880 , the Court summed up the situation by declaring, "It is certainly now too late to doubt the power of Congress to govern the Territories. There have been some differences of opinion as to the particular clause of the Constitution from which the power is derived, but that it exists has always been conceded."

It makes no difference to any of the arguments advanced in this Article whether the power to govern territories stems from the District clause, the territories clause, the power to acquire territory, or any combination of the three. As far as formalists are concerned, the power in any case inust be exercised in a manner consistent with the Constitution and all its vital structural provisions.

\section{IV \\ WHERE TO GO FROM HERE?}

The formalist vision of a constitutional territorial regime is vastly

328. Id. at $542-43$.

329. Id. at 542 ("The Constitution confers absolutely on the government of the Union, the powers of making war, and of making treaties; consequently, that government possesses the power of acquiring territory, either by conquest or by treaty."); U.S. CoNST. art. I, § 8, cl. 11; id. art. II, § 2, cl. 2. The Court subsequently held that the government could also exercise a measure of dominion over territory that was discovered or otherwise acquired by American citizens. See Jones v. United States, 137 U.S. 202, 212 (1890).

330. See United States v. Gratiot, 39 U.S. (14 Pet.) 526, 537-38 (1840).

331. 60 U.S. (19 How.) 393 (1857).

332. See id. at 443, 448-49. For a painstaking breakdown of the various jnstices' positions on this question, see Currie, The Constitution in the Supreme Court: Article IV and Federal Powers, 1836-64, 1983 DUKe L.J. 695, 732 \& n.242.

333. See Dred Scott, 60 U.S. (19 How.) at 432-42. The conclnsion is difficult to defend. It is true enough, as the opinion in Dred Scott argues, that the principal-and perhaps even the solepurpose of the territories clanse was to provide for the temporary management of the Northwest Territory until it could be formed into new states. The language of the clause is general however: as long as something is "the territory or other property" of the United States, it comes within the terms of the provision, whatever its purpose or intendment may have been.

334. 101 U.S. 129 (1880).

335. Id. at 132. For a summary of the various constitutional sources in which the Court has grounded a power to acquire territory, see Reno, The Power of the President to Acquire and Govern Territory, 9 GEO. WASH. L. REv. 251, 256 \& n.21 (1941). 
different froin the regime that has been in place for the past two hundred years. According to the formalist, all territorial laws, even those pertaining strictly to local affairs, must be enacted by the national political branches. Those laws must then be executed by officers of the United States who are appointed in conformity with the appointments clause. All judicial proceedings in the territories, whether involving national or local law, must take place before tribunals whose judges satisfy the tenure and salary provisions of article III. If Congress and the President want to have local judges with teinporary appointments, that's just too bad. If the people of the territorijes want a participatory share in their governments, that's also too bad. And if Congress and the President share this desire for soine ineasure of local autonomy for the territory, either to prepare the population for independence or simply to express a preference for deinocracy over autocracy, that seeins to be too bad as well. The picture, in suin, appears one of constitutionally mandated colonialism, which is not likely to go over well at cocktail parties, legal syinposia, or congressional committee hearings. ${ }^{336}$

So what are the options for formalists? I can envision five options, soine of which raise issues far beyond the scope of this Article, but all of which deserve brief mention.

The first option for formalists is to einbraee colonialism with, if not normative fervor, then at least equamimity. This was in fact the position of no less a figure than Gouverneur Morris, the drafter of the territories clause of article IV. In a letter written in 1803, he explained his efforts to write colonialism into the Constitution:

"I always thought that when we should acquire Canada and Louisiana, it would be proper to govern them as provinces and allow them no voice in our councils. In wording the third section of the fourth article, I went as far as circumstances would permit to establish the exclusion. Candor obliges me to add my belief, that had it been more pointedly expressed, a strong opposition would have been made."337

He did a fine job. The territories clause empowers Congress to enact rules and regulations respecting "the Territory or other Property belonging to the Umited States." ${ }^{338}$ As noted earlier, ${ }^{339}$ the territories are thus lumped together with, and treated exactly like, "other property," such as

336. It is therefore interesting to note that America's turn-of-the-century colonialists were fervent antiformalists. The debate at that time concerned, in substance, whether the Bill of Rights had to be extended to our newly acquired overseas territories. See supra notes 103-04 and accoinpanying text. An affirmative answer, it was thought, would make governance-and hence possession -of those territories impossible, thus preventing America from becoining an overseas empire.

337. Letter from Gouverneur Morris to Henry W. Livingston (Dec. 4, 1803), quoted in De Linna v. Bidwell, 182 U.S. 1, 63 (1901) (Argunent for Plaintiffs in Error).

338. U.S. ConsT. art. IV, § 3 , cl. 2.

339. See supra text accompanying note 293 . 
staplers and paper clips, which suggests that article IV is structured to facilitate their treatment as colonies. This alternative is, lrowever, unlikely to generate nuch entlusiasm among today's formalists.

A more plausible response, and the option that I would be inclined to adopt, is to look for political substitutes for strict self-governance. One of the often overlooked virtues of formalism is that it is . . . well, formalistic. Once you know the rules, you can work around them, and quite often achieve your substantive goals witlout any constitutional inonkey business. For example, the Constitution may forbid the outriglit election of territorial governors, but it does not prohibit the President and Senate froin announcing, as a inatter of policy, that they will appoint as governor whomever the territorial population chooses in a free, albeit formalistically nonbinding, election. Similarly, Congress could agree simply to rubber-stamp the proposals of territorial "legislatures," perhaps by adopting rules affording fast-track, no-debate treatınent to bills of local concern "enacted" by elected territorial bodies. ${ }^{340}$ Since such territorial legislation would in fact coinply witl all of the formalities of article I, the letter of the Constitution would be satisfied, and so would I.

It is true that these substitute inechanisins place territorial selfgovernance at the mercy of the national political branches, but that is true im any event: no one (or at least no one wlo takes the Constitution at all seriously) nraintaims that Congress is constitutionally required to permit territories to govern theinselves. Thus, while it is possible that, for exainple, Congress could clioose not to adopt particular iteins of legislation "enacted" by territorial goverming bodies, tliat would not differ significantly froin the present situation, where Congress always lias the option of nullifying locally enacted laws. ${ }^{341}$ Perliaps there is a symbolic difference between requiring Congress to enact territorial laws and permitting it to repeal thein, but that is liardly a consequence startling enougli to inake formalists lose any sleep.

A third possible response is interpretative. The evidence is overwhelming that at the time of the framing, nuany of the Constitution's frainers and ratifiers expected, or intended, thiat territories would be largely self-governing, at least to the extent of liaving elected legislatures. ${ }^{342}$ While iny analysis lias linked formalism to textualism, that is a product of iny perliaps idiosyncratic definition of formalisin. ${ }^{343}$

340. Cf. Breyer, The Legislative Veto After Chadha, 72 GEo. L.J. 785, $792-95$ (1984) (suggesting that Congress could largely duplicate the legislative veto that was held unconstitutional in Chadha through similar procedural machinations).

341. See supra note 53. Similarly, if Congress today disapproves of the outcome of a territorial election, it can simply abolish the office.

342. See supra text accompanying notes 295-97. The evidence on elected governors is far inore equivocal. See supra text accompanying notes $81-90$.

343. See supra text accompanying notes 22-23. 
Another formalist could inaintain that my limited boundaries of formalism need to be expanded at this point to include "intentionahists," who might wish to argue that the available evidence of original intentions must color our view of the relationship between the District and the territories clauses on the one hand and the Constitution's structural provisions on the other.

One might respond to this arguinent by invoking the plainly contrary intentions of the person who drafted the territories clause, ${ }^{344}$ but given the evident consensus concerning territorial self-governance in 1787 , this would be quibbling. If the task of constitutional interpretation is indeed to discover the intentions of soine group of persons-the framers, the ratifiers, or both-with respect to specific questions, then at least much of the foregoing analysis is plainly misconceived. Thus, the need to distinguish carefully between textualisin and intentionalism is superbly illustrated by the problems of territorial governance. A strict reading of the text and structure of the Constitution-my formalist approachleads to conclusions almost certainly at odds with the intentions of inost of the relevant participants in the Constitution's framing and adoption. To justify my view that the strict reading should prevail over the intentions, however, would require a comparative assessment of textualism and intentionalism. ${ }^{345}$ For now, this interpretative response can ouly be noted, not evaluated.

As a fourth response, formalists who are unhappy with the consequences of formalism can advocate changing the Constitution through the ainendment processes that it prescribes: the procedures of article $\mathrm{V}^{346}$ or direct national referenda. ${ }^{347}$ Or a fifth and final response could smiply be to abandon formalism on the grounds that it is inorally unacceptable. Without meaning to endorse, even by miphication, this kind of "bottom-line" approach to constitutional theory, I would simply remind those who find this last move tempting that departures from formalism have led to the doctrime of territorial incorporation, the adjudication of cases in territories by politically dependent tribunals, and some of the worst-reasoned opinions ever to blight the pages of the United States Reports. Given the relative ease with which mechanisms of territorial

344. See, e.g., supra text accompanying note 337.

345. See supra note 22. It would be convemient if I could cite to an extended discussion of the subject elsewhere, but unfortunately my reasons for embracing textualism-or what $I$ have elsewhere called "wooden originalism," Lawson, supra note 23, at 22-rest on epistemological and moral premises that differ radically from those of my fellow travellers.

346. U.S. CoNsT. art. V.

347. This mode of amendment may sound bizarre, especially coming from a formalist. It struck me as bizarre as well when Professor Amar first proposed it to me. He was right and I was wrong. See Amar, supra note 91 (argining that the people of the United States have an unenumerated right to amend the Constitution by direct referendum). 
self-governance, if desired, can be established within a formalist framework, the price of abandoning formalisin seeins very high indeed. 